Georgia State University

ScholarWorks @ Georgia State University

$11-2021$

\title{
Testing the Effects of Adaptive Learning Courseware on Student Performance: An Experimental Approach
}

\author{
Grace Eau \\ Georgia State University, graceo@gsu.edu \\ Derek Hoodin \\ dhoodin1@student.gsu.edu \\ Tareena Musaddiq \\ The University Of Michigan, tareenam@umich.edu
}

Follow this and additional works at: https://scholarworks.gsu.edu/econ_facpub

Part of the Economics Commons

\section{Recommended Citation}

Eau, Grace; Hoodin, Derek; and Musaddiq, Tareena, "Testing the Effects of Adaptive Learning Courseware on Student Performance: An Experimental Approach" (2021). ECON Publications. 86.

doi: https://doi.org/10.1002/soej.12547

This Article is brought to you for free and open access by the Department of Economics at ScholarWorks @ Georgia State University. It has been accepted for inclusion in ECON Publications by an authorized administrator of ScholarWorks@ Georgia State University. For more information, please contact scholarworks@gsu.edu. 


\title{
Testing the Effects of Adaptive Learning Courseware on Student Performance: An Experimental Approach ${ }^{1}$
}

\author{
Authors: Grace $\mathrm{Eau}^{2 \dagger}$, Derek Hoodin ${ }^{3}$, Tareena Musaddiq ${ }^{4}$ \\ Department of Economics, Georgia State University, Atlanta, GA, USA
}

\begin{abstract}
An increasing number of college and university courses are being offered in an online format. Even for courses offered face-to-face, instructors are increasingly turning toward use of online platforms to help with student learning, especially for courses with high enrollment. This study tests the efficacy of adaptive learning platforms in a sample of undergraduate students in a large urban university, using an experimental design that compares the learning outcomes of students in classrooms that used an adaptive learning tool to those who did not. The results indicate that better performing students, particularly female students, benefit the most from using adaptive learning tools.
\end{abstract}

Keywords: Adaptive Learning · Experimental Design $\cdot$ Undergraduate Economics

Word count: 7,379

Figure count: 8

Table count: 11

\footnotetext{
${ }^{1}$ This project is funded by the Gates Foundation. The Personalized Learning Consortium of the Association of Public Land Grant Universities oversaw the grant.

${ }^{2 \dagger}$ Lead author correspondence.

3 dhoodin1@gsu.edu

${ }^{4}$ University of Michigan, tareenam@umich.edu
} 


\section{Introduction}

Online offerings may become a regular, more widely available feature in higher education to meet the needs of students who require more flexibility in their schedule. As colleges and universities consider offering more courses with greater flexibility for their students in terms of time and place of instruction, there is concern about how learning may be impacted in online settings. University administrators, teachers, and students alike wish to minimize the impact on learning and are on the lookout for innovative ways to optimize online learning. With limited inperson contact between instructors and students for online classes, guiding students who are at different levels of learning within the same classroom is an important concern.

Adaptive learning courseware is just one of the latest innovations in classroom technology. Recently made available for mass market distribution by textbook publishers, adaptive learning platforms use machine learning and advanced algorithms to guide students based on their responses to questions and on their self-evaluation of each skill area. These platforms claim to enhance student learning and metacognition and provide an individualized learning path with a non-linear approach to instruction and remediation.

Some early research, such as Sosin et al. (2004), evaluates how PowerPoint, email, and similar technology impact student performance. More recent studies tend to focus on how well students perform in online courses compared to blended or in-person courses. Alpert, Couch, and Harmon (2016) and Bettinger et al. (2017) show that online education significantly lowers student learning outcomes, as measured by course grades and continued enrollment at the university. Students in blended courses, however, seem to perform no worse than students in courses that meet face-to-face (Alpert, Couch, and Harmon 2016; Cosgrove and Olitsky 2015).

Indeed, in their survey of the literature on teaching economics to undergraduates, Allgood, Walstad, and Siegfried (2015) find that most studies report a negative association between online 
instruction and student learning outcomes. The authors also find that most studies which examine individual pieces of technology show insignificant effects on student performance. This is similar to the conclusion reached by Johnson and Meder (2021) in their meta-analysis of technology interventions. Even so, Allgood, Walstad, and Siegried (2015) hypothesize that new technology could positively impact student performance if it represents a large enough change for students. Along this line, Bosshardt and Chiang (2016) document the factors associated with students choosing to enroll in a course where the lectures are recorded live, and those recordings are made available to the students. They find that students who are already familiar with this technology, who live long distances from campus, and who hold positive attitudes towards distance learning are more likely to opt for courses with this format.

This study investigates the effectiveness of adaptive learning courseware in an undergraduate economics course at a large, urban, public university in the United States by using a classroom experiment to control for student characteristics. Students enrolled in the treatment classrooms used an adaptive learning platform for their homework assignments whereas students in the control classrooms used an online platform without the embedded adaptive learning component. We estimate the difference in performance on various student learning outcomes, including progress measured by improvement on a standardized test in the subject, total points scored over the semester, course grade, and likelihood of completing the course with a passing grade.

To the best of our knowledge, this study is unique in that it tests the efficacy of the adaptive learning software by using the progress that students make on a standardized test taken at the beginning and end of the course as an outcome measure. We are also able to control for a rich set of student characteristics using university administrative data. Our results show that students who 
enter the course with a high level of pre-knowledge, particularly women, benefit the most from using the adaptive learning courseware.

A major potential advantage of adaptive learning courseware lies in how it operates. These platforms adjust to each student's interaction with the system and demonstrated performance, anticipating the type of content and resources each student will need at a specific point in time in order to make progress in learning the material. Based on the student's progress, the adaptive learning courseware then chooses a path to develop and enhance the student's understanding of the subject. In doing so, these systems are also able to identify students with low prior knowledge and provide them with a high level of instructional support.

Adaptive learning platforms can also aid students by providing instructors with detailed information on how their students are learning so they can intervene if a student begins to struggle. Put differently, adaptive learning platforms provide a rich footprint of how each student is learning, enabling instructors to deliver individual instruction at scale. Together, the use of analytics and adaptive learning allow instructors to personalize each student's learning experience and advisement both online and in-person.

Intuitively, these mechanisms - creating a personalized learning experience and providing more information to instructors - support the claim that adaptive learning enhances student learning. However, the impact of adaptive learning platforms needs to be formally evaluated. Are adaptive learning platforms improving student learning, and which group of students are getting the benefits? The proportion of women among students majoring in economics has remained at about one-third for several decades despite numerous interventions and an increasing number of female faculty members who could serve as role models to young women (Emerson, McGoldrick, and Siegfried 2018). Could adaptive learning courseware help young women excel in their 
principles courses? $?^{5}$ In this study we try to answer this question for undergraduate students enrolled in an introductory economics course. Prior research shows that letter grades in introductory courses can impact the probability of women choosing economics as a major by up to a 50 percent increase (McEwan, Rogers and Weerapana 2021).

The rest of this article is organized as follows. Section 2 provides a literature review on adaptive learning courseware. Section 3 describes the study design and experimental details. Sections 4 and 5 describe the data and empirical methodology. Section 6 presents the results of the study. A discussion of the results and conclusions are provided in Section 7 and Section 8, respectively.

\section{Literature Review}

As the use of electronic devices has increased, adaptive learning platforms have become more sophisticated. ${ }^{6}$ According to Essalmi et al. (2010), adaptive learning platforms can provide more than 58,000 personalized strategies based off just ten personalized parameters; the authors do not, however, provide any evidence of efficacy of these platforms. One stream of literature indicates that adaptive learning platforms may impede learning due to a mismatch between content difficulty and learner ability (Chen 2008). This mismatch arises when platforms use a generic algorithm to consider courseware difficulty, concept continuity, and each student's response and metacognition level. This mismatch then leads to a cognitive overload and a failure of the personalized learning path.

\footnotetext{
${ }^{5}$ Representation and success of women in the field of economics is a growing concern. Researchers have documented the effectiveness of various interventions designed to increase success of women in this field (see e.g., Emerson, McGoldrick, and Siegfried 2018).

${ }^{6}$ For details on the design and mechanics of adaptive learning platforms and how they can tailor the learning process to meet each student's needs, see Brusilovsky and Peylo (2003), Di Bitonto et al. (2013), and Mulwa et al. (2010).
} 
Adaptive learning platforms should therefore be evaluated on their efficacy towards student learning and on their cost effectiveness. This need is especially urgent as platforms transition from proof-of-concept computer programs to vendor-made online applications intended for mass distribution. If the platforms improve student learning, then there would be a strong justification for their adoption. If the platforms do not markedly improve student learning but do lower costs, then there would still be a benefit to their use. In this study, we focus on the former and evaluate how the use of an adaptive learning platform impacts student learning and performance.

Much of the relevant literature in this domain has focused on grade improvement, course passing rate, and course withdrawal rate. For example, in their review of the literature on intelligent tutoring systems, Kulik and Fletcher (2016) find that the systems improve student test scores by about two-thirds of a standard deviation on average. A meta-analysis by Scholastic Reading Inventory (SRI) Education shows that adaptive learning platforms are associated with slight improvements on common learning assessments as well as on course completion, although they find no discernable improvement on course grade (Yarnall, Means, and Wetzel 2016). A similar report by Education Growth Advisors finds an 18 percent increase in the passing rate and a 47 percent drop in withdrawals in math courses at Arizona State University, and a 7 percent increase in the passing rate in math courses based on data from 700 university and community college students. The report also finds that students in an Open Learning Initiative's introductory statistics course completed the class 25 percent faster compared to students in a face-to-face class (Newman, Stokes, and Bryant 2013).

Allgood, Walstad, and Siegfried (2015) identify several factors which make researching and evaluating new teaching tools, such as use of adaptive learning platforms, difficult. These factors include the following: (1) insufficient instructional time devoted to the new method, (2) 
nonrandom assignment of students to treatment and control groups, (3) the use of learning outcomes that may not fully capture the effect of the treatment, (4) implementation of the new teaching method varying by instructor or university, (5) students reacting to the new teaching method by using the efficiency gains to devote more time elsewhere, and (6) Institutional Review Board limiting research control. Many of these limiting factors apply equally to studies that examine new technology and can be seen in the studies cited above.

For example, these results suggest that adaptive learning courseware may boost student performance. However, the outcomes used in the literature to measure the success of the adaptive learning technology - grades and course completion - do not perfectly correspond to student learning. A more established and effective way to measure a pedagogic tool is student progress, which is measured by the difference between pre-knowledge and post-knowledge. In addition, previous evaluations have not always chosen an appropriate control group. Students in the Open Learning statistics course, for instance, should have been compared to students enrolled in an online course without the adaptive learning component. Similarly, Santana et al. (2016) study the effect of adaptive learning on Brazilian student enrolled in mathematics and Portuguese courses, but in their experimental design the control group did not use a comparable online learning platform.

In our study, we address a number of these shortcomings. To start, we conducted a classroom-level experiment in which we randomly assigned sections of the same course, taught by the same instructor, into treatment and control, minimizing any concerns about differences in implementation due to different instructors (addressing factor 4). This assignment was designed such that the only difference between students attending the treatment versus the control classroom was the adaptive learning platform (thereby addressing factors 2 and 4). Second, in addition to 
grades and course completion - the two outcomes most commonly used in the literature - we also used the progress students made on a standardized pre/post exam on subject knowledge to measure the success of the adaptive learning component (addressing factor 3 ). Third, our adaptive learning courseware was embedded into every pre-lecture homework assignment (addressing factor 1). Finally, the courseware required that students demonstrate mastery over the content material before they would be allowed to progress through the assignment (addressing factor 5; see section III on Experimental Design for more information).

\section{Experimental Design}

\section{III.A Adaptive Learning Platform}

For this study, we selected the McGraw Hill Connect platform. In 2016, the Bill and Melinda Gates Foundation funded a $\$ 9$ million grant package. The purpose of the grant funding was to improve the quality of postsecondary education and lower the cost. The Association of Public Land Grant Universities (APLU) oversaw the grant through the Personalizing Learning with Adaptive Courseware project. ${ }^{7}$ The APLU set a list of criteria that an adaptive learning platform must meet in order to be eligible for the project. At the time of this study, the APLU had approved 21 adaptive courseware suppliers and products. The full list of criteria and approved products are included in Appendix B.

Among the list of possible interface choices, not all of the approved products included economics content. Some only provided a course shell that instructors would have to fill in themselves. McGraw Hill Connect was selected as the adaptive courseware for several reasons. First, McGraw Hill is a well-established publisher with customer service support for both instructors and students. Second, the content was deemed satisfactory by the instructors. Finally,

\footnotetext{
7 For details, see https://www.aplu.org/projects-and-initiatives/personalized-learning-consortium/plc-projects/plcadaptive-courseware/. Details on the selection criteria are provided in Appendix B.
} 
the cost of the textbook was comparable with existing textbooks. Students could pay $\$ 75$ for sixmonth access directly from the McGraw Hill website. The university bookstore might have offered a slightly different price due to mark up.

Appendix Figures A1 through A3 detail the learning experience for students using the adaptive learning platform. Figure A1 shows the introduction page for the courseware, Figure A2 shows an example student progress report, and Figure A3 shows an example of some remediation options available after a student selects an incorrect answer. The courseware functions by first presenting students with a content question. They are then asking how confident they feel in their answer. Possible answers to the confidence question include "I know it," "Think so," "Unsure," and "No idea." The courseware will give students options for remediation and automatically reroute them to similar content questions if they answer the content question incorrectly or answer it with low reported confidence.

Appendix Figures A4.A through A4.D show an example of an individualized learning path. The student is initially asked a question about monetary policy and then his or her confidence in answering the question (Figure A4.A). The courseware provides immediate feedback (Figure A4.B) and, since the student's answer was only partially correct, the courseware provides some remediation (Figure A4.C). The student is then asked another monetary policy question (Figure A4.D).

\section{III.B Experimental Details}

We conducted the experiment with students enrolled in a principles-level economics course taught by a single instructor at a public university. The university is known for its diverse student population, of which 58 percent are Pell-Grant eligible. Students in both treatment and control classrooms used the McGraw Hill Connect software for their homework assignments, but students 
in the treatment classrooms had the adaptive learning component enabled while the control group did not.

The experiment ran for three semesters: Spring, Summer, and Fall of 2018. Table A1 provides details on the treatment and control classrooms. To minimize differences due to instruction, the experimental sample was limited to sections (or classrooms) taught by the same instructor, both within and across the three terms. Over the three terms, this resulted in a total of nine sections (or classrooms), with five assigned to treatment and the remaining four left as controls. Assignment to treatment within each term was stratified to ensure a mix of modality of instruction (or lecture delivery format) - face-to-face and online. Over the three terms then, four sections were online, with an enrollment of 580, while the remaining five face-to-face sections had an enrollment of 750 .

These classrooms had the same instructor and were identical in course content and grading scheme. Students chose which section they wanted to enroll in. At the time of registration students had no knowledge about the online platforms that would be used and whether or not the section they were enrolling in would be using an adaptive learning platform. The only information available to students on the university course registration website when they registered for the course was the name of the course, name of the instructor, the section number, schedule of the class in terms of day and time, and whether the modality of instruction was in-person or online. The title of the course and the name of the instructor are common to all sections in our experimental sample, across treatment and control and for all the three terms. From the students' perspective, the only visible difference at the time of registration in any given semester was the timing of each class and the mode of instruction. Both control and treatment classrooms were offered at a mix of varying times during the day, across the three terms. 
Students were evaluated based on three unit exams each worth 20 percent of their final grade, one cumulative final exam worth 30 percent, and online homework assignments worth the remaining 10 percent. The online homework assignments were further divided between pre-lecture homework assignments (5 percent) due before the respective lecture and post-lecture homework assignments (5 percent) due after the relevant module was completed.

The adaptive learning feature was used to deliver pre-lecture homework in the treatment classrooms, but a static online learning system was used to deliver an alternative pre-lecture homework in the control classrooms. The post-lecture homework assignments did not have any adaptive learning component and were the same for both treatment and control classrooms. The pre-lecture homework consisted mostly of formative assessments that targeted lower levels of Bloom's taxonomy, whereas the post-lecture homework was more complex and required applications and interpretation of concepts. The aim of the pre-lecture homework was to enable a flipped classroom environment so that classroom time may be devoted to more complex examples and applications. ${ }^{8}$ These homework assignments, however, were not a pre-requisite to attending the class (i.e., students were allowed to attend the class even if they had not completed the homework, but they lost out on points that contributed towards the overall score for the grade).

While the pre-homework assignments form only 5 percent of the grade, they serve a larger purpose when it comes to learning. While it may be possible to accommodate an individual student's need in small group settings, catering to such needs is not feasible in classes with large enrollments. Online Adaptive learning courseware provides an alternative by allowing

\footnotetext{
${ }^{8}$ The details regarding the design of the homework in terms of assessment purposes and their relevance to Bloom's taxonomy are based on information collected from the course instructor. Bloom's taxonomy categorizes six levels of intellectual behavior and is often represented visually as a pyramid. Moving from the bottom of the pyramid to the top, these six levels are (1) remembering, (2) understanding, (3) applying, (4) analyzing, (5) evaluating, and (6) creating. For more information, see Anderson and Krathwohl (2001).
} 
individualized learning paths for larger settings. The courseware adjusts tasks and their difficulty based on a student's prior knowledge, competency, and their self-assessment. The purpose of adaptive learning is to improve student learning experience and help them study/learn better. So, while the homework assignments might not carry a large weight in the overall course grade per se, they may be important for their learning experience. The adaptive learning platform is implicitly teaching students how to learn and so the knowledge/techniques they learn through the platform may spill over into other areas of their learning and the course. Improved learning efficiency and a better learning experience through these systems may lead to better student performance. This makes it important to assess the impact on overall performance in the course and not just on homework scores.

\section{Data}

Data pertaining to the variables of interest can be broadly classified into two main categories: student learning outcomes and student characteristics (obtained from the university administrative records). The outcomes of interest for this study include progress made on the Test of Understanding College Economics ${ }^{9}$ (TUCE, a standardized test taken at the beginning and end of the course), the total points earned in the course, an indicator for whether or not a student passed the course, and the grade earned. We limit our sample to students for whom the data are complete. This removes students who withdrew from the course, never completed the post-TUCE, or had missing student characteristics (e.g., transfer students with missing GPA and credit history). Doing so ensures the sample is consistent across the analysis. ${ }^{10}$

\footnotetext{
${ }^{9}$ For more information, see Walstad and Rebeck (2008) and Watts and Schaur (2011).

${ }^{10} \mathrm{We}$ also run a regression to check whether the observations dropped out of our analytical sample due to missing information are predicted by treatment. The estimate on our variable of interest, an indicator term for enrollment in a class using the adaptive learning courseware, is negative and not statistically significant (coef: -0.0149). This indicates attending a treatment classroom is not systematically associated with the missing data.
} 
Table 1 Column 1 presents the summary statistics for the study sample (all students in the untreated and treated classrooms). The sample consists mostly of traditional college-age students and is 52.3 percent female. The sample is also racially diverse: 41.8 percent of the students identify as black, 22.8 percent as white, 18.1 percent as Asian, and 9.4 percent as Hispanic, while the rest identify as two or more races. Most students enrolled in the course are either freshmen (25.08 percent) or sophomores (35.53 percent) and are intended pre-business majors (48.30 percent). Only a small handful are intended economics majors (2.94 percent). As for their math experience, roughly two-thirds of the students meet or exceed the recommended math courses. ${ }^{11}$

In terms of their average performance, the students on average completed 8.7 pre-lecture homework assignments out of a total of 11, scored an 11 out of 30 on the pre-TUCE exam, and improved their score to a 16.44 on the post-TUCE exam. Looking at the letter grades awarded, 37.9 percent earned an A, 28.01 percent earned a B, 18.11 percent earned a $\mathrm{C}$, and 15.94 percent received a $\mathrm{D}, \mathrm{F}$, or $\mathrm{W}$. Just over 67 percent of the students in the sample participated in the online version of the course, as opposed to face-to-face.

Table 1 Columns 2 and 3 present the summary statistics for the students in the untreated and treated groups. Column 4 shows the difference between the two groups (columns $3-2$ ), and Column 5 shows the results of a difference of means test (t-test). Across most of the student characteristics, the difference between those in treatment and control classrooms is not significant. This suggests students across the two types of classrooms were not different, specifically in terms of pre-TUCE score, prior GPA, race, intended major, and math background, many of which may be potential confounders in case the sample was not balanced. Percentage female, percentage opting for online modality of instruction, and percentage students who were in their senior years

\footnotetext{
${ }^{11}$ The recommended math courses are not pre-requisites per se; students are still able to enroll in the economics course even if they have not completed the math courses. They are, however, strongly encouraged by the university.
} 
do however have a significant t-test statistic. This may happen when the randomization is at a higher level (i.e. classroom as opposed to student level randomization) and the number of units of treatment (classroom) are small. We control for all these covariates in our estimations. We also look at heterogeneity effects by gender in our later analysis. To supplement those results, Table A2 and A3 show summary statistics for men and women, respectively.

\section{Empirical Methodology}

We begin by estimating the impact of treatment on our measure of progress, called adjusted progress, which is defined as the difference between a student's TUCE score before (pre-TUCE) and after (post-TUCE) taking the course, divided by the difference between the maximum attainable score (i.e., 30) and the pre-TUCE score. This measure accounts for the possibility that gains from students with low scores on the pre-test are potentially very different from the gains possible for students with high scores on the pre-test, and measures actual improvement as a proportion of the possible improvement. We estimate the effect of the treatment through the following equation:

$$
\text { Adjusted Progress }_{i s t}=\beta_{0}+\beta_{1} \text { Treat }_{s}+\boldsymbol{\beta} X_{i s t}+\zeta_{t}+\varepsilon_{\text {ist }}
$$

where Adjusted Progress ist $_{\text {is }}$ as defined above for student $i$, in classroom $s$, in term $t$. Treat $t_{s t}$ is a binary indicator equal to one if student $i$ was in the treatment classroom and zero otherwise. $X_{i s t}$ is a vector of demographic and academic controls. The demographic controls include student $i$ 's age, gender, and race. Controls related to prior academic performance include credit hours completed to date, GPA to date, number of pre-lecture homework assignments completed over the semester, pre-TUCE score, and delivery method of the course (in-person vs. online). $\zeta_{t}$ are semester (or term) fixed effects that control for any differences that might arise due to the semester of enrollment. 
Our study is unique in its ability to estimate the impact of adaptive learning conditional on the student's prior knowledge of economics. In particular, GPA serves as a measure of overall student achievement in the past while pre-TUCE score specifically captures student $i$ 's understanding of economics prior to taking the course. Our primary coefficient of interest is $\beta_{1}$ which captures the impact of attending a classroom using the adaptive learning platform versus a traditional non-adaptive type of course. A positive value of $\beta_{1}$ would indicate that attending a classroom that used the adaptive learning platform was effective in helping the students learn and understand the material better, resulting in a higher progress measure and better performance relative to students in the control group.

The literature on adaptive learning suggests that men and women might respond differently to such a learning treatment (Arroyo et al. 2013). We therefore estimate Equation (1) separately by gender and test for statistically significant differences in the estimates for men and women. ${ }^{12}$ Further, as described earlier, our data allow us the unique opportunity to estimate whether the impact of the adaptive learning treatment differs across students with varying prior knowledge of the subject. In other words, our data allow us to test whether students benefited more (or less) depending on where they fall along the distribution of pre-TUCE scores. We therefore also estimate Equation (1) restricting our sample to students scoring above and below average on the pre-TUCE, as well as those with scores in the top $75^{\text {th }}$ percentile and bottom $25^{\text {th }}$ percentile of the distribution.

Next, we estimate the impact of treatment on total points scored by the end of the semester. In our data, total points scored is the sum of points earned by the student in all graded components

\footnotetext{
${ }^{12} \mathrm{We}$ also estimate models where, instead of running separate regressions for each gender, we run one regression that includes an interaction term for adaptive learning and gender. We then test for joint significance between the adaptive learning term and the interaction term. See Table A6.
} 
of the class (three unit exams, one final exam, and the homework assignments) over the course of the semester, weighted by the grading scheme. To that end, we estimate the following equation:

$$
\text { Score }_{i s t}=\alpha_{0}+\alpha_{1} \text { Treat }_{s}+\alpha X_{i s t}+\zeta_{t}^{\prime}+\varepsilon_{i s t}
$$

where $\alpha_{1}$ is the coefficient of interest in Equation (2) and all other variables are defined as in Equation (1). The coefficient on $\alpha_{1}$ allows us to estimate whether being in a treatment classroom leads to an increase in the overall points scored throughout the semester. The total score captures the impact on the understanding of the course material throughout the semester. In addition, it serves as a broader measure than Adjusted Progress.

Lastly, we estimate the impact of treatment on final grades. We do so in two ways. First, we estimate the impact on the probability of passing the course. For this, we estimate a linear probability model with a binary outcome variable equal to one if the student passed the course and zero otherwise:

$$
\text { Pass }_{i s t}=\gamma_{0}+\gamma_{1} \text { Treat }_{s}+\gamma X_{i s t}+\zeta_{t}^{\prime \prime}+\varepsilon_{i s t}
$$

where the variables are described as earlier for Equations (1) and (2). A positive $\gamma_{1}$ in Equation (3) indicates that attending a treatment classroom increased the probability of a student passing the course relative to the untreated group. With an average pass rate of approximately 65 percent, it is important to estimate if students benefited enough to gain on the pass/fail margin.

While Equation (3) allows us to estimate the impact on the pass/fail margin, we also estimate whether assignment to the adaptive learning platform increased the probability of achieving a higher grade across the entire distribution of grades (A-F). We believe this is important for two reasons. First, students may need to achieve a particular letter grade in order to maintain a certain grade point average to apply for (or maintain) scholarships, honor society memberships, and for transferring credits across institutions. Second, our earlier proposed analysis of looking at 
the impact on probability of passing the course shows the impact on one aspect of the achievement distribution. This ordered logit analysis helps us see the impact at various points of the grade distribution.

For this, we estimate an ordered logit on the letter grade awarded at the end of the semester. Suppose there is a single latent variable $y_{i}^{*}$ given by:

$$
y_{i}^{*}=x_{i}^{\prime} \beta+u_{i}
$$

As $y_{i}^{*}$ crosses a series of increasing thresholds, we move up the order of alternatives, in this case grades. For example, for a very low $y^{*}$ the corresponding grade is $\mathrm{F}$, for $y^{*}>a_{1}$ the grade improves to a $\mathrm{D}$, for $y^{*}>a_{2}$ the grade improves to a $\mathrm{C}$, and so on. In general, for an $n$ alternative ordered model:

$$
y_{i}=\mathrm{j} \text { if } a_{j-1}<y_{i}^{*} \leq a_{j}
$$

Then:

$$
\begin{gathered}
\operatorname{Pr} \operatorname{Pr}\left[y_{i}=j\right]=\operatorname{Pr}\left[a_{j-1}-x_{i}^{\prime} \beta<u_{i} \leq a_{j}-x_{i}^{\prime} \beta\right] \\
\text { or } \mathrm{F}\left[a_{j}-x_{i}^{\prime} \beta\right]-\mathrm{F}\left[a_{j-1}-x_{i}^{\prime} \beta\right]
\end{gathered}
$$

where $\mathrm{F}$ is the $\mathrm{CDF}$ of $u_{i}$, which, in the case of logit, is the logistic distribution. For correct interpretability we estimate the odds ratio associated with each grade. The odds ratio predicts the probability of receiving the higher grade versus the lower grade between each grade cutoff.

\section{Results}

Table 2 Columns 1 through 3 present the regression results for adjusted progress. Column 1 shows the results for the full sample, Column 2 shows the results for the male students, and Column 3 shows the results for the female students. Panels B and C in Table 2 show results for a further subdivision of the sample based on the students' performance on the pre-TUCE exam (i.e. divides the sample by prior knowledge of the subject). Reading from top to bottom, Panel A 
presents the results for all students, and Panels B and C present the results for a sub-sample of students who scored above and below average on the pre-TUCE.

For the full sample, attending a treatment classroom impacts adjusted progress positively (coef: $0.044, \mathrm{p}=0.040$ ). The impact is larger in magnitude and is statistically significant for female students (coef: $0.0682, \mathrm{p}=0.020$ ) and smaller and imprecisely estimated for male students (coef: 0.019). This outcome ranges from 1 (indicating the student earned on the post-TUCE all or 100\% of the points previously missed on the pre-TUCE) to -3.6 (indicating the student missed on the post-TUCE more than the number of points missed on the pre-TUCE, in this case 3.6 times as many points), and has a mean of 0.28 and a standard deviation of 0.27 . These results therefore imply that the adaptive learning courseware helped students answer, on average, four percent more of the questions they previously missed on the pre-TUCE. For women, the effect is closer to seven percent.

When looking at students with above average pre-TUCE scores (Panel C), the results become larger in magnitude for the full sample (coef: 0.081, $\mathrm{p}=0.058$ ) and for women (coef: $0.144, \mathrm{p}=0.012$ ). So, students with an above average pre-TUCE scores who were assigned to the adaptive learning system, on average, correctly answered eight percent more of their previously missed questions on the TUCE exam than their peers. This is equivalent to almost a quarter standard deviation higher for the adjusted progress measure. Similarly, women with above average pre-TUCE scores, on average, correctly answered 14 percent more of the questions they previously answered incorrectly on the pre-TUCE. We find no statistically significant impact on adjusted progress for students scoring above the $75^{\text {th }}$ percentile of pre-TUCE (See Table 2, Panel B).

Columns 4, 5, and 6 present the regression results for total points awarded in the course and are read in the same manner as Columns 1 through 3. In Panel C, however, we find a positive 
and statistically significant increase $(\mathrm{p}=0.005)$ of 23 points (out of a total of 1000 total points) for students who scored above average on the pre-TUCE test. As was the case for the adjusted progress measure, we find a larger effect for female students (coef: $38.8, \mathrm{p}=0.003$ ). This is a substantial change in overall total score and may potentially push some students above the threshold for a better grade. We study this change on grade earned later in Table 4 . We do not find any statistically significant impact for students with pre-TUCE scores in $75^{\text {th }}$ percentile and above (Panel B).

Columns 7, 8, and 9 present the regression results for pass/fail and exhibit the same subsample analysis as before. All results shown in Columns 7 through 9 are from a linear probability model. These results show that attending a treatment classroom increases the probability of passing the course for all students (coef: $0.032, p=0.026$ ) or with above average pre-TUCE scores (coef: $0.075, \mathrm{p}=0.079$ ). ${ }^{13,14}$ Here too, the effect is larger and statistically significant for women (coef: 0.092, $\mathrm{p}=0.060)$.

We also estimate the effect of the treatment by gender for adjusted progress, total points, and on the probability of passing the course by interacting an indicator for the student being female with the treatment indicator. This analysis complements our existing results in Table 2 where we estimate separate specifications by gender. Results in Table A6 show that estimates on the interaction term are in-line with our results from separate specifications in Table 2.

In Table 3, we look at the impact for students with below average pre-TUCE scores and for those in the bottom $25^{\text {th }}$ percentile of pre-TUCE scores. Here, we find that enrolling in a class that uses the adaptive learning courseware is associated with marginally significant increases in adjusted progress for men with below average pre-TUCE scores (coef: 0.049, $\mathrm{p}=0.092$ ) and in

\footnotetext{
${ }^{13}$ One concern regarding analysis in Tables 2 and 3 might be that we control for pre-TUCE scores while the outcome measure is also constructed using pre-TUCE scores. We estimate the specifications in Table 2 excluding the preTUCE control. Results in Table A4 and A5 show consistent results with Tables 2 and 3, respectively.

${ }^{14}$ Full results for specifications in Table 2, with estimates for all controls, are shown in Table A7.
} 
the probability that women who scored in the bottom $25^{\text {th }}$ percentile of the pre-TUCE pass the course (coef: $0.072, \mathrm{p}=0.082$ ). Somewhat surprisingly, we also find a reduced probability that men who scored in the bottom $25^{\text {th }}$ percentile pass the course (coef: $\left.-0.125, p=0.086\right)$. Tables 2 and 3 also report the estimates for the number of pre-homework assignments completed. Almost every pre-homework estimate is positive for the adjusted progress measure, which is expected. Most the pre-homework estimates are also positive and significant for the other outcomes.

Finally, we test for statistically significant differences between the estimates for men and women (on both the reported adaptive learning term and the number of pre-homework assignments completed). For the adaptive learning term, statistically significant differences exist for the effect on total points for men and women who scored above average on their pre-TUCE and for the likelihood of passing the course for those who scored in the bottom $25^{\text {th }}$ percentile. As for the number of pre-homework assignments completed, there are significant differences for the effect on total points (all TUCE scores, top $75^{\text {th }}$ percentile, below average, and bottom $25^{\text {th }}$ percentile) and for the pass/fail margin (all TUCE scores, top $75^{\text {th }}$ percentile, below average, and bottom $25^{\text {th }}$ percentile). In almost every case where the differences in the estimates for men and women are statistically significant, the estimate for women is larger in magnitude.

Table 4 presents the regression results from using an ordered logit model on the letter grade awarded. Table 4 also shows the odds ratio, which is interpreted as the ratio of the probability of receiving one higher letter grade compared to not receiving one higher letter grade. Table 4 is otherwise read in the same way as Tables 2 and 3. As in Table 2, all students with higher-thanaverage pre-TUCE scores (Panel B) or scores in the top $75^{\text {th }}$ percentile (Panel D) were more likely to receive a higher letter grade when attending a treatment classroom. Moreover, women with 
above average pre-TUCE scores were more than twice as likely to receive a higher letter grade (coef: $1.008, \mathrm{p}=0.000$, odds ratio 2.74 ).

\section{Discussion}

In this study, we analyze whether using an adaptive learning platform might be beneficial for student performance. Classrooms for an introductory economics course at a large, urban public university in the U.S. were assigned to either treatment or control. Our results indicate that adaptive learning may improve outcomes for high-performing students, particularly women, and help them succeed in a principles-level economics course.

One may wonder why above average students, especially women, benefit the most from using the adaptive learning courseware. While our study cannot speak to the mechanisms and reasons behind the impact we see, specifically on certain types of students, our results appear consistent with the literature from other fields, such as educational psychology, that study selfregulation in boys and girls. Self-regulated learners use metacognition to identify gaps in their knowledge, plan their approach, monitor their learning, and adjust their strategies as needed. Nonself-regulated learners, by contrast, see their intelligence as fixed and attribute their successes and failures to forces beyond their control (Butler and Winne 1995; Perry, Phillips, and Hutchinson 2006; Pintrich and Schunk 2002; Winne and Perry 2000; Arroyo et al. 2013). If students with above average pre-TUCE score in our study were also on average more likely to be self-regulated, then we can expect them to benefit most from the adaptive courseware. Previous research has also found that self-regulated students show optimal use of learning software, instead of trying to game the system by abusing hints or rapidly clicking through the available answers until the correct one is revealed (R. S. Baker et al. 2004; R. Baker et al. 2008; R. S. J. d. Baker et al. 2013). 
We also draw some insights from research on the use of educational software to understand our findings and discuss possible explanations for them, although we cannot test for any of these and hence cannot regard them as the definitive reasons for behind our findings. Prior research shows that educational software that focuses on summative assessments may not be beneficial for girls, while software that relies on formative assessment - like the McGraw Hill Connect which delivered the pre-lecture homework assignments - helps them. Fiore (1999) and Luik $(2011,3)$ show, for example, that girls benefit from exercises and activities, rather than competition, especially when working in a group with computers. Forgasz and Leder $(2006 ; 2008)$ show that girls are likely to believe in themselves as capable learners in mathematics when the instruction is placed on investigative skills. Adaptive learning courseware allows students to investigate by providing formative assessments with remediation. In contrast, boys have been shown to not value formative assessments as much girls (Gunn et al. 2002), possibly explaining some of the difference in the impact we see between the two genders in our study.

Differences in how men and women use adaptive learning platforms may also have implications for women's participation in subjects such as economics in which they have been historically underrepresented despite ongoing and sometimes costly interventions. To provide just one example, since 1995, only about 30 percent of all B.A. and Ph.D. degrees in economics have been awarded to women (Bayer and Rouse 2016). In 2014, to help reach gender parity, Harvard economist and then-AEA president Claudia Goldin initiated the Undergraduate Women in Economics Challenge. Participating institutions received $\$ 12,500$ court blanche in grant funding, which they then used to experiment with ways to encourage female students to major in economics (Avilova and Goldin 2018). 
Our results, which show a greater positive impact of the adaptive learning courseware on women, may be indicative of adaptive learning platforms accommodating how women engage with instructional technology, especially it subjects where women have lower self-efficacy, such as in economics. If this is indeed the case, this technology may be used as a tool to encourage female students and building their self-efficacy. Prior research shows that praise and encouragement to persist in the field for high achievers results in a higher number of women choosing economics as a major (Bedard, Dodd and Lundberg 2021). While our study cannot explicitly measure the self-efficacy channel, if adaptive learning does indeed make women confident about their grasp on the subject, this might encourage them consider taking economics as a major.

For college administrators in search of ways to improve their online offerings, this intervention can be free of cost: if instructors are already using an online homework system provided by vendors such as McGraw Hill, then using the adaptive learning platform will not raise the financial burden on the college or its students. Meanwhile, the cost to instructors varies from a small change in the set-up to enable the adaptive learning feature to building a new online course from scratch. Adaptive learning courseware may therefore be an important component - alongside others uncovered by initiatives like Goldin's Challenge - in raising female performance and participation in economics and related fields, particularly at the introductory level.

\section{Conclusion}

Textbook publishers have taken advantage of improvements in computing power to create more sophisticated adaptive learning platforms compared to what was previously available. These adaptive learning platforms dynamically collect information on student knowledge, ability, and motivation, and use that data to adjust the timing and difficulty of the course content being 
delivered. In doing so, these platforms also help students identify gaps in their own knowledge and provide instructors with analytics on how well their students are learning. The idea is that these platforms will provide students with their own customized learning experience, which in turn enhances their learning in a cost-effective way. The research on adaptive learning, however, has so far produced inconclusive results. As universities continue to search for ways to provide students with more flexible scheduling options, they may turn towards new instructional technology like adaptive learning courseware. It is therefore important to analyze if these customized learning experiences, such as the ones provided by this instructional technology, can aid universities in this goal.

This study used an experimental design to evaluate the efficacy of adaptive learning courseware toward student learning. Classrooms for a principles-level undergraduate economics course were assigned to an online adaptive learning tool while the untreated classrooms used an online tool without the adaptive component. Their progress on a standardized test taken at the beginning and end of the course, as well as the total points they earned, their letter grade, and their likelihood of passing the course were evaluated.

Our results indicate that adaptive learning may be beneficial to certain students, particularly high performing students and women, while not negatively effecting the performance of others. While our study cannot speak to the reasons behind the impacts we estimate, prior research from various disciplines provides possible explanations. We suspect that although female students may start out with lower self-efficacy than male students in math-intensive disciplines such as economics, the adaptive learning courseware might help raise their self-efficacy by focusing on formative assessments. 
Adaptive learning is gender-neutral in its conception and implementation: the software is designed without regard for gender and can be used to its full potential by every student - that women benefit more may be a consequence of how they engage with the system. Previous research has shown that students who perform well in their introductory classes are more likely to major in economics (Jensen and Owen 2001; Owen 2010; Rask and Tiefenthaler 2008). Better performance because of adaptive learning platforms may encourage women to persist in majoring in economics. While we cannot measure the impact of adaptive learning platforms on future course-taking, our results do point to an exciting area for future research. 


\section{References}

Allgood, Sam, William B. Walstad, and John J. Siegfried. 2015. "Research on Teaching Economics to Undergraduates." Journal of Economic Literature 53 (2): 285-325. https://doi.org/10.1257/jel.53.2.285.

Alpert, William T., Kenneth A. Couch, and Oskar R. Harmon. 2016. "A Randomized Assessment of Online Learning." American Economic Review 106 (5): 378-82. https://doi.org/10.1257/aer.p20161057.

Anderson, Lorin W., and David R. Krathwohl. 2001. A Taxonomy for Learning, Teaching, and Assessing: A Revision of Bloom's Taxonomy of Educational Objectives. Complete ed. Longman.

https://search.ebscohost.com/login.aspx?direct=true\&AuthType=ip,shib\&db=cat06552a $\& \mathrm{AN}=\mathrm{gsu} .9911515533402952 \&$ site$=\mathrm{eds}-\mathrm{live} \& \mathrm{scope}=$ site $\&$ custid=gsu1 .

Arroyo, Ivon, Winslow Burleson, Minghui Tai, Kasia Muldner, and Beverly Park Woolf. 2013. "Gender Differences in the Use and Benefit of Advanced Learning Technologies for Mathematics." Journal of Educational Psychology 105 (4): 957-69. https://doi.org/10.1037/a0032748.

Avilova, Tatyana, and Claudia Goldin. 2018. "What Can UWE Do for Economics?" AEA Papers and Proceedings 108 (May): 186-90. https://doi.org/10.1257/pandp.20181103.

Baker, Ryan S. J. d., A. T. Corbett, I. Roll, K. R. Koedinger, V. Aleven, M. Cocea, A. Hershkovitz, A. M. J. B. de Caravalho, A. Mitrovic, and M. Mathews. 2013. "Modeling and Studying Gaming the System with Educational Data Mining." In International Handbook of Metacognition and Learning Technologies, edited by Roger Azevedo and Vincent Aleven, 28:97-115. New York, NY: Springer New York. https://doi.org/10.1007/978-1-44195546-3 7.

Baker, Ryan Shaun, Albert T. Corbett, Kenneth R. Koedinger, and Angela Z. Wagner. 2004. “OffTask Behavior in the Cognitive Tutor Classroom: When Students Game the System.” In Proceedings of the SIGCHI Conference on Human Factors in Computing Systems, 38390. ACM.

Baker, Ryan, Jason Walonoski, Neil Heffernan, Ido Roll, Albert Corbett, and Kenneth Koedinger. 2008. "Why Students Engage in 'Gaming the System' Behavior in Interactive Learning Environments.” Journal of Interactive Learning Research 19 (2): 185-224.

Bayer, Amanda, and Cecilia Elena Rouse. 2016. "Diversity in the Economics Profession: A New Attack on an Old Problem." Journal of Economic Perspectives 30 (4): 221-42. https://doi.org/10.1257/jep.30.4.221.

Bedard, K., Dodd, J. and Lundberg, S., 2021, May. Can Positive Feedback Encourage Female and Minority Undergraduates into Economics? In AEA Papers and Proceedings (Vol. 111, pp. 128-32). 
Bettinger, Eric P., Lindsay Fox, Susanna Loeb, and Eric S. Taylor. 2017. "Virtual Classrooms: How Online College Courses Affect Student Success." American Economic Review 107 (9): 2855-75. https://doi.org/10.1257/aer.20151193.

Bloom, B. S., Englehart, M. D., Furst, E. J., Hill, W. H., \& Krathwohl, D. R. (1956). Taxonomy of Educational Objectives: Handbook I Cognitive Domain. New York, New York: David McKay Company, 144-45.

Bosshardt, William, and Eric P. Chiang. 2016. "Targeting Teaching Lecture Capture Learning: Do Students Perform Better Compared to Face-to-Face Classes?" Southern Economic Journal 82 (3): 1021-38. https://doi.org/10.1002/soej.12084.

Brusilovsky, Peter1, peterb@mail.sis.pitt.edu, and Christoph2 Peylo christoph.peylo@sla.de. 2003. "Adaptive and Intelligent Web-Based Educational Systems." International Journal of Artificial Intelligence in Education (IOS Press) 13 (2-4): 159-72.

Butler, Deborah L., and Philip H. Winne. 1995. "Feedback and Self-Regulated Learning: A Theoretical Synthesis.” Review of Educational Research 65 (3): 245-81.

Chen, Chih-Ming. 2008. "Intelligent Web-Based Learning System with Personalized Learning Path Guidance." Computers \& Education $51 \quad$ (2): 787-814. https://doi.org/10.1016/j.compedu.2007.08.004.

Cosgrove, Sarah B., and Neal H. Olitsky. 2015. "Knowledge Retention, Student Learning, and Blended Course Work: Evidence from Principles of Economics Courses." Southern Economic Journal 82 (2): 556-79. https://doi.org/10.1002/soej.12045.

Di Bilonlo, Pierpaolo, Teresa Roselli, Veronica Rossano, and Maria Sinatra. 2013. "Adaptive ELearning Environments: Research Dimensions and Technological Approaches." International Journal of Distance Education Technologies 11 (3): 1-11. https://doi.org/10.4018/jdet.2013070101.

Emerson, Tisha L. N., KimMarie McGoldrick, and John J. Siegfried. 2018. "The Gender Gap in Economics Degrees: An Investigation of the Role Model and Quantitative Requirements Hypotheses." Southern Economic Journal 84 (3): 898-911. https://doi.org/10.1002/soej.12247.

Essalmi, Fathi, Leila Jemni Ben Ayed, Mohamed Jemni, Kinshuk, and Sabine Graf. 2010. “A Fully Personalization Strategy of E-Learning Scenarios." Computers in Human Behavior, Emerging and Scripted Roles in Computer-supported Collaborative Learning, 26 (4): 58191. https://doi.org/10.1016/j.chb.2009.12.010.

Fiore, Catherine. 1999. "Awakening the Tech Bug in Girls." Learning and Leading with Technology 26: 10-17. 
Forgasz, Helen J., and Gilah C. Leder. 2008. "Beliefs about Mathematics and Mathematics Teaching." In The Handbook of Mathematics Teacher Education: Volume 1, 173-92. Brill Sense.

Gunn, Cathy, Sheila French, Hamish McLeod, Mae McSporran, and Gráinne Conole. 2002. "Gender Issues in Computer-Supported Learning." ALT-J 10 (1): 32-44.

Jensen, E. J., \& Owen, A. L. 2001. Pedagogy, gender, and interest in economics. The Journal of Economic Education, 32(4), 323-343.

Johnson, Marianne, and Martin E. Meder. 2021. "A Meta-Analysis of Technology: Interventions in Collegiate Economics Classes." The Journal of Economic Education 52 (1): 1-16. https://doi.org/10.1080/00220485.2020.1845261.

Kulik, James A., and J. D. Fletcher. 2016. "Effectiveness of Intelligent Tutoring Systems: A MetaAnalytic Review." Review of Educational Research 86 (1): 42-78. https://doi.org/10.3102/0034654315581420.

Leder, Gilah C., and Helen J. Forgasz. 2006. "Affect and Mathematics Education: PME Perspectives." In Handbook of Research on the Psychology of Mathematics Education, 403-27. Brill Sense.

Luik, Piret. 2011. "Would Boys and Girls Benefit from Gender-Specific Educational Software?" British Journal of Educational Technology 42 (1): 128-44.

McEwan, P.J., Rogers, S. and Weerapana, A., 2021, May. Grade Sensitivity and the Economics Major at a Women's College. In AEA Papers and Proceedings (Vol. 111, pp. 102-06).

Mulwa, Catherine, Seamus Lawless, Mary Sharp, Inmaculada Arnedillo-Sanchez, and Vincent Wade. 2010. "Adaptive Educational Hypermedia Systems in Technology Enhanced Learning: A Literature Review." In Proceedings of the 2010 ACM Conference on Information Technology Education, 73-84. SIGITE '10. New York, NY, USA: ACM. https://doi.org/10.1145/1867651.1867672.

Newman, Adam, Peter Stokes, and G. Bryant. 2013. "Learning to Adapt: A Case for Accelerating Adaptive Learning in Higher Education." Boston, MA: Education Growth Advisors.

Owen, A. L. 2010. Grades, gender, and encouragement: A regression discontinuity analysis. The Journal of Economic Education, 41(3), 217-234.

Perry, Nancy E., Lynda Phillips, and Lynda Hutchinson. 2006. "Mentoring Student Teachers to Support Self-Regulated Learning." Elementary School Journal 106 (3): 237-54. https://doi.org/10.1086/501485.

Pintrich, Paul R., and Dale H. Schunk. 2002. Motivation in Education: Theory, Research, and Applications. Prentice Hall. 
Rask, K., \& Tiefenthaler, J. 2008. The role of grade sensitivity in explaining the gender imbalance in undergraduate economics. Economics of Education Review, 27(6), 676-687.

Santana, Sivaldo J. de, Ranilson Paiva, Ig Ibert Bittencourt, Patrícia Espinheira Ospina, Rafael de Amorim Silva, and Seiji Isotani. 2016. "Evaluating the Impact of Mars and Venus Effect on the Use of an Adaptive Learning Technology for Portuguese and Mathematics." In 2016 IEEE 16th International Conference on Advanced Learning Technologies (ICALT), 31-35. https://doi.org/10.1109/ICALT.2016.58.

Sosin, Kim, Betty J Blecha, Rajshree Agarwal, Robin L Bartlett, and Joseph I Daniel. 2004. "Efficiency in the Use of Technology in Economic Education: Some Preliminary Results." American Economic Review 94 (2): 253-58. https://doi.org/10.1257/0002828041301623.

Walstad, William B., and Ken Rebeck. 2008. "The Test of Understanding of College Economics." American Economic Review 98 (2): 547-51.

Watts, Michael, and Georg Schaur. 2011. "Teaching and Assessment Methods in Undergraduate Economics: A Fourth National Quinquennial Survey." The Journal of Economic Education 42 (3): 294-309.

Winne, Philip H., and Nancy E. Perry. 2000. "Measuring Self-Regulated Learning." In Handbook of Self-Regulation, 531-66. Elsevier.

Yarnall, Louise, Barbara Means, and Tallie Wetzel. 2016. "Lessons Learned from Early Implementations of Adaptive Courseware." SRI Education, April. 
Table 1: Summary Statistics

\begin{tabular}{|c|c|c|c|c|c|}
\hline & $\begin{array}{l}\text { Col 1: Mean } \\
\text { Full Sample }\end{array}$ & $\begin{array}{c}\text { Col 2: } \\
\text { Mean } \\
\text { Untreated }\end{array}$ & $\begin{array}{c}\text { Col 3: } \\
\text { Mean } \\
\text { Treated }\end{array}$ & $\begin{array}{c}\text { Col 4: } \\
\text { Diff } \\
(3)-(2)\end{array}$ & $\begin{array}{c}\text { Col 5: } \\
\operatorname{Pr}(|t|>c)\end{array}$ \\
\hline \multicolumn{6}{|l|}{ Demographic } \\
\hline Age & 22.03 & 22.22 & 21.89 & 0.33 & 0.4255 \\
\hline Female (\%) & $52.32 \%$ & $59.06 \%$ & $47.30 \%$ & 11.76 & $0.0030^{* * *}$ \\
\hline \multicolumn{6}{|l|}{ Race $(\%)$} \\
\hline Asian & $18.11 \%$ & $19.20 \%$ & $17.30 \%$ & 1.91 & 0.5346 \\
\hline Black & $41.80 \%$ & $39.49 \%$ & $43.51 \%$ & -4.02 & 0.3061 \\
\hline Hispanic & $9.44 \%$ & $9.06 \%$ & $9.73 \%$ & -0.67 & 0.7731 \\
\hline White & $22.76 \%$ & $24.64 \%$ & $21.35 \%$ & 3.29 & 0.3251 \\
\hline Two or more races & $7.89 \%$ & $7.61 \%$ & $8.11 \%$ & -0.50 & 0.8162 \\
\hline \multicolumn{6}{|l|}{ Institutional } \\
\hline Entering GPA & 2.89 & 2.92 & 2.87 & 0.05 & 0.3718 \\
\hline Entering hours & 54.69 & 57.64 & 52.50 & 5.13 & $0.0679^{*}$ \\
\hline \multicolumn{6}{|l|}{ Academic level (\%) } \\
\hline Freshman & $25.08 \%$ & $22.10 \%$ & $27.30 \%$ & -5.20 & 0.1322 \\
\hline Sophomore & $36.53 \%$ & $36.59 \%$ & $36.49 \%$ & 0.11 & 0.9776 \\
\hline Junior & $23.22 \%$ & $22.83 \%$ & $23.51 \%$ & -0.69 & 0.8381 \\
\hline Senior & $15.17 \%$ & $18.48 \%$ & $12.70 \%$ & 5.78 & $0.0430^{* *}$ \\
\hline \multicolumn{6}{|l|}{ Major (\%) } \\
\hline Pre-business & $48.30 \%$ & $46.01 \%$ & $50.00 \%$ & -3.99 & 0.3167 \\
\hline Business & $0.77 \%$ & $0.36 \%$ & $1.08 \%$ & -0.72 & 0.3032 \\
\hline Economics & $2.94 \%$ & $3.99 \%$ & $2.16 \%$ & 1.82 & 0.1754 \\
\hline \multicolumn{6}{|l|}{ Math Experience (\%) } \\
\hline No math & $21.83 \%$ & $20.65 \%$ & $22.70 \%$ & -2.05 & 0.5333 \\
\hline Basic math & $0.46 \%$ & $0.36 \%$ & $0.54 \%$ & -0.18 & 0.7422 \\
\hline Pre-reqs & $42.48 \%$ & $53.99 \%$ & $51.35 \%$ & 2.63 & 0.5080 \\
\hline Trig or calc. & $11.14 \%$ & $11.23 \%$ & $11.08 \%$ & 0.15 & 0.9520 \\
\hline Advanced math & $14.09 \%$ & $13.77 \%$ & $14.32 \%$ & -0.56 & 0.8410 \\
\hline \multicolumn{6}{|l|}{ Performance } \\
\hline \# Pre-HW Completed & 8.68 & 9.03 & 8.42 & 0.62 & $0.0052^{* * *}$ \\
\hline Pre-TUCE Score & 11.01 & 10.69 & 11.26 & -0.56 & 0.1361 \\
\hline Post-TUCE Score & 16.44 & 15.99 & 16.77 & -0.78 & $0.0520^{*}$ \\
\hline Adjusted Progress & 0.27 & 0.25 & 0.28 & -0.03 & 0.2682 \\
\hline Online class (\%) & $67.03 \%$ & $79.35 \%$ & $57.84 \%$ & 21.51 & $0.0000^{* * *}$ \\
\hline \multicolumn{6}{|l|}{ Class Grade (\%) } \\
\hline A & $37.93 \%$ & $35.51 \%$ & $39.73 \%$ & -4.22 & 0.2746 \\
\hline B & $28.01 \%$ & $27.17 \%$ & $28.65 \%$ & -1.47 & 0.6803 \\
\hline $\mathrm{C}$ & $18.11 \%$ & $19.93 \%$ & $16.76 \%$ & 3.17 & 0.3013 \\
\hline $\mathrm{D}, \mathrm{F}$, or $\mathrm{W}$ & $15.94 \%$ & $17.39 \%$ & $14.86 \%$ & 2.53 & 0.3863 \\
\hline \# Observations & 646 & & & & \\
\hline
\end{tabular}

Notes: ${ }^{*} \mathrm{p}<0.1,{ }^{* *} \mathrm{p}<0.05,{ }^{* * *} \mathrm{p}<0.01$ 
Table 2: Regression Results for All and High TUCE Students

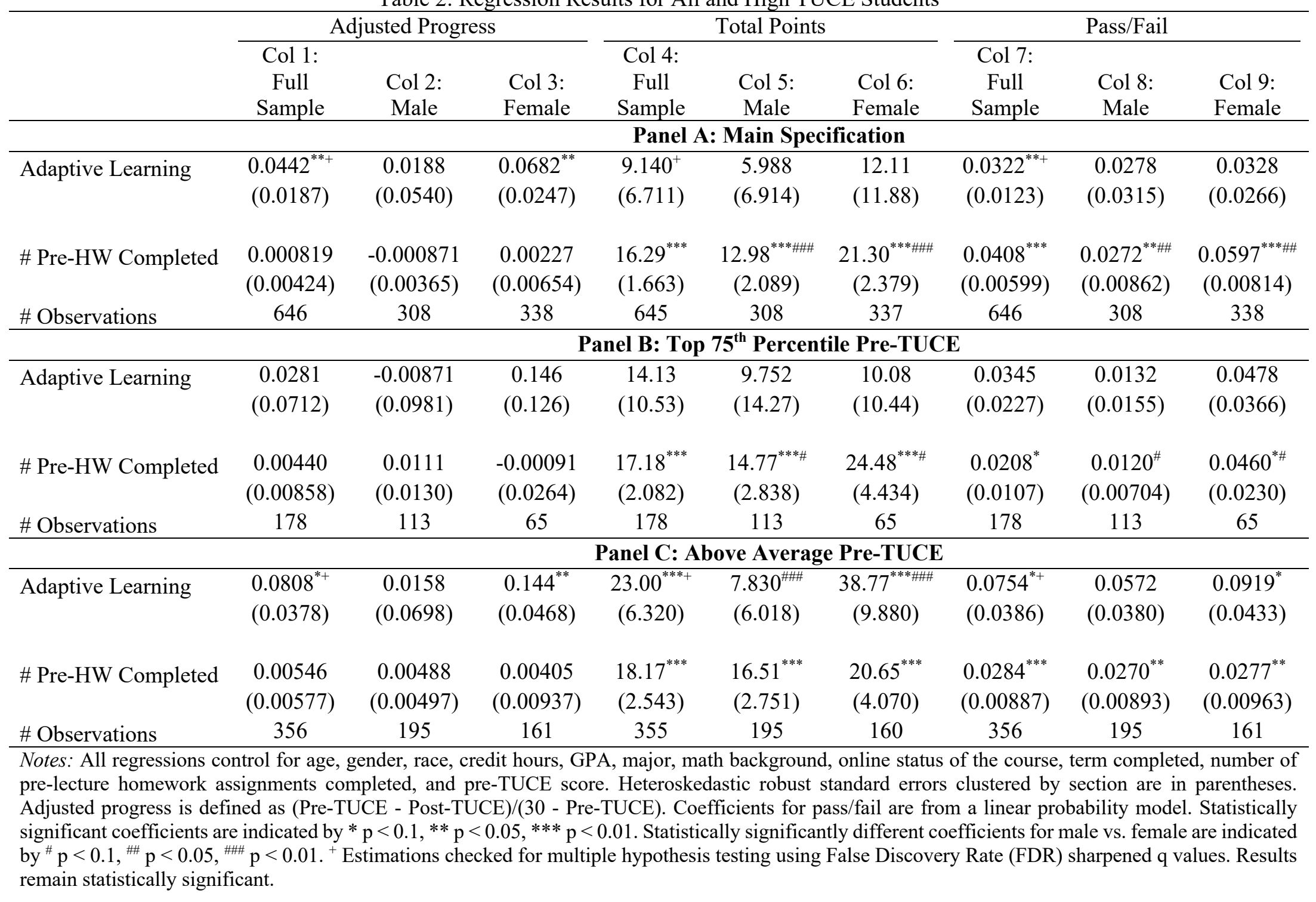


Table 3: Regression Results for Low TUCE Students

\begin{tabular}{|c|c|c|c|c|c|c|c|c|c|}
\hline & \multicolumn{3}{|c|}{ Adjusted Progress } & \multicolumn{3}{|c|}{ Total Points } & \multicolumn{3}{|c|}{ Pass/Fail } \\
\hline & $\begin{array}{l}\text { Col 1: } \\
\text { Full } \\
\text { Sample }\end{array}$ & $\begin{array}{l}\text { Col 2: } \\
\text { Male }\end{array}$ & $\begin{array}{l}\text { Col 3: } \\
\text { Female }\end{array}$ & $\begin{array}{l}\text { Col 4: } \\
\text { Full } \\
\text { Sample }\end{array}$ & $\begin{array}{l}\text { Col 5: } \\
\text { Male }\end{array}$ & $\begin{array}{l}\text { Col 6: } \\
\text { Female }\end{array}$ & $\begin{array}{l}\text { Col 7: } \\
\text { Full } \\
\text { Sample }\end{array}$ & $\begin{array}{l}\text { Col 8: } \\
\text { Male }\end{array}$ & $\begin{array}{l}\text { Col 9: } \\
\text { Female }\end{array}$ \\
\hline & \multicolumn{9}{|c|}{ Panel A: Below Average Pre-TUCE } \\
\hline Adaptive Learning & $\begin{array}{c}0.0245 \\
(0.0188)\end{array}$ & $\begin{array}{c}0.0485^{*} \\
(0.0254)\end{array}$ & $\begin{array}{c}0.0192 \\
(0.0360)\end{array}$ & $\begin{array}{c}2.173 \\
(20.05)\end{array}$ & $\begin{array}{c}7.999 \\
(17.68)\end{array}$ & $\begin{array}{l}-0.0891 \\
(24.33)\end{array}$ & $\begin{array}{c}0.0101 \\
(0.0363)\end{array}$ & $\begin{array}{c}0.0196 \\
(0.0651)\end{array}$ & $\begin{array}{c}0.0187 \\
(0.0309)\end{array}$ \\
\hline \# Pre-HW Completed & $\begin{array}{l}-0.00290 \\
(0.00358)\end{array}$ & $\begin{array}{c}-0.00200 \\
(0.00240)\end{array}$ & $\begin{array}{l}-0.00252 \\
(0.00664)\end{array}$ & $\begin{array}{l}16.09^{* * *} \\
(3.287)\end{array}$ & $\begin{array}{c}11.29^{* * \# \#} \\
(4.778)\end{array}$ & $\begin{array}{c}21.34^{* * * \# \#} \\
(3.043)\end{array}$ & $\begin{array}{l}0.0573^{* * *} \\
(0.00791)\end{array}$ & $\begin{array}{c}0.0307^{\# \# \#} \\
(0.0176)\end{array}$ & $\begin{array}{c}0.0821^{* * * \# \#} \\
(0.00602)\end{array}$ \\
\hline \# Observations & 290 & 113 & 177 & 290 & 113 & 177 & 290 & 113 & 177 \\
\hline & \multicolumn{9}{|c|}{ Panel B: Bottom $25^{\text {th }}$ Percentile Pre-TUCE } \\
\hline Adaptive Learning & $\begin{array}{c}0.0288 \\
(0.0264)\end{array}$ & $\begin{array}{c}0.0308 \\
(0.0337)\end{array}$ & $\begin{array}{c}0.0357 \\
(0.0464)\end{array}$ & $\begin{array}{l}-1.712 \\
(24.15)\end{array}$ & $\begin{array}{l}-22.40 \\
(22.05)\end{array}$ & $\begin{array}{c}3.682 \\
(23.33)\end{array}$ & $\begin{array}{c}0.0123 \\
(0.0512)\end{array}$ & $\begin{array}{c}-0.125^{* \# \# \#} \\
(0.0640)\end{array}$ & $\begin{array}{c}0.0718^{* \# \#} \\
(0.0361)\end{array}$ \\
\hline \# Pre-HW Completed & $\begin{array}{c}0.00156 \\
(0.00620)\end{array}$ & $\begin{array}{c}-0.00253 \\
(0.00686)\end{array}$ & $\begin{array}{c}0.0111 \\
(0.0109)\end{array}$ & $\begin{array}{l}19.39^{* * *} \\
(4.673)\end{array}$ & $\begin{array}{c}8.593^{\# \#} \\
(6.048)\end{array}$ & $\begin{array}{c}30.34^{* * * \# \#} \\
(3.995)\end{array}$ & $\begin{array}{c}0.0547^{* * *} \\
(0.0122)\end{array}$ & $\begin{array}{c}0.0185^{\# \#} \\
(0.0247)\end{array}$ & $\begin{array}{c}0.0986^{* * * \# \#} \\
(0.0183)\end{array}$ \\
\hline \# Observations & 168 & 65 & 103 & 168 & 65 & 103 & 168 & 65 & 103 \\
\hline
\end{tabular}

Notes: All regressions control for age, gender, race, credit hours, GPA, major, math background, online status of the course, term completed, number of prelecture homework assignments completed, and pre-TUCE score. Heteroskedastic robust standard errors clustered by section are in parentheses. Adjusted progress is defined as (Pre-TUCE - Post-TUCE)/(30 - Pre-TUCE). Coefficients for pass/fail are from a linear probability model. Statistically significant coefficients are indicated by $* \mathrm{p}<0.1,{ }^{* *} \mathrm{p}<0.05,{ }^{* * *} \mathrm{p}<0.01$. Statistically significantly different coefficients for male vs. female are indicated by ${ }^{\#} \mathrm{p}<0.1,{ }^{\#} \mathrm{p}<0.05$, ${ }^{\# \#} \mathrm{p}$ $<0.01$. 
Table 4: Ordered Logit Results for Letter Grade

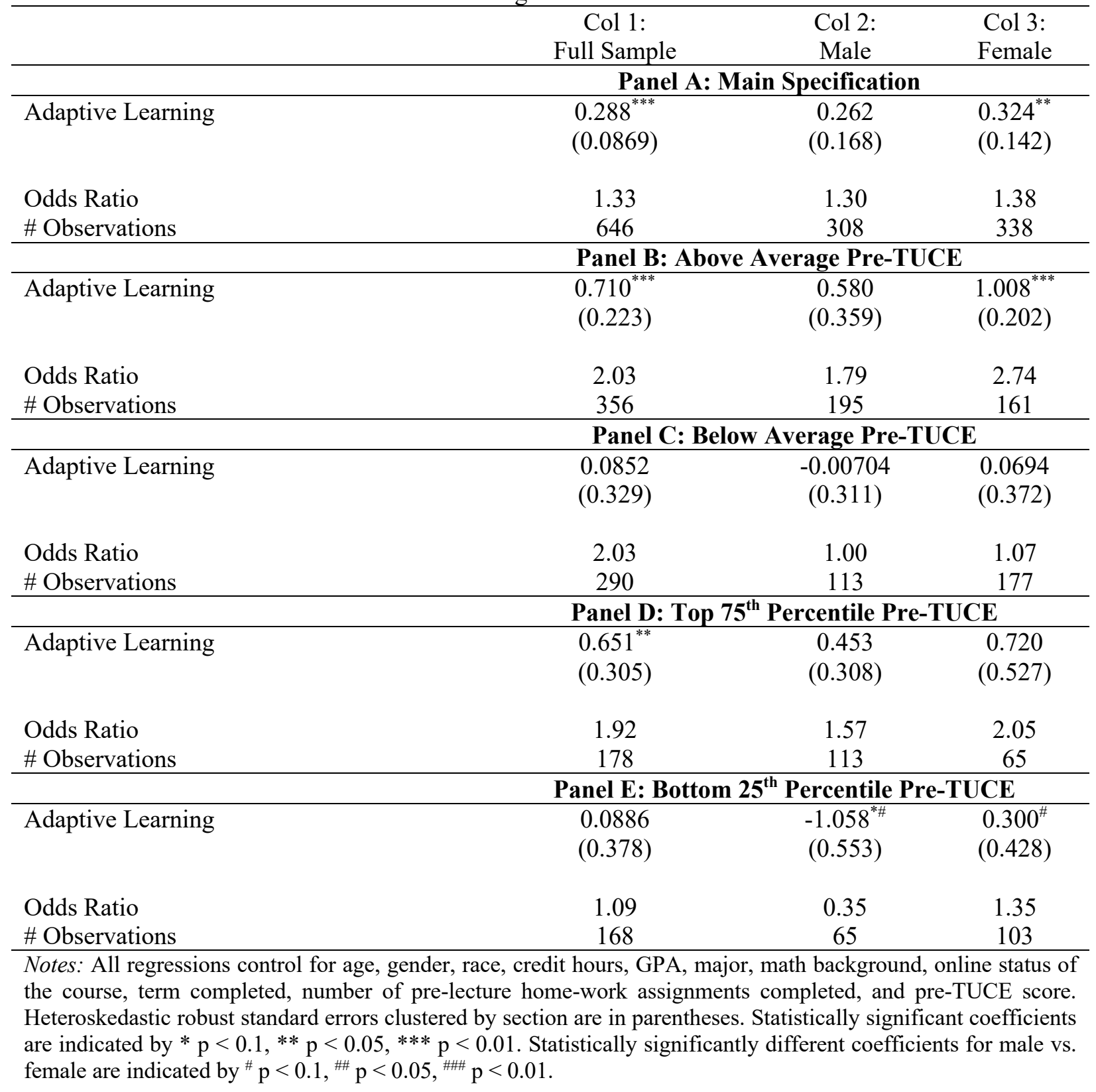


Table A1: Section Assignment to Treatment and Control

\begin{tabular}{cccc}
\hline $\begin{array}{c}\text { Treatment vs. } \\
\text { Control }\end{array}$ & $\begin{array}{c}\text { Lecture } \\
\text { Delivery } \\
\text { Format }\end{array}$ & $\begin{array}{c}\text { Enrollment } \\
\text { Excluding } \\
\text { Withdrawals }\end{array}$ & $\begin{array}{c}\text { Enrollment } \\
\text { Including } \\
\text { Withdrawals }\end{array}$ \\
\hline Adaptive & Online & 144 & 170 \\
Adaptive & Face-to-face & 156 & 170 \\
Non-adaptive & Face-to-face & 150 & 173 \\
\hline Adaptive & Online & 60 & 72 \\
Non-adaptive & Face-to-face & 60 & 76 \\
\hline Adaptive & Face-to-face & 152 & 170 \\
Adaptive & Online & 142 & 169 \\
Non-adaptive & Face-to-face & 150 & 161 \\
Non-adaptive & Online & 139 & 169 \\
\hline
\end{tabular}

Notes: Totals show raw enrollment, not the number of students included in the regression sample. 
Table A2: Summary Statistics - Men Only

\begin{tabular}{|c|c|c|c|c|c|}
\hline & $\begin{array}{l}\text { Col 1: Mean } \\
\text { Full Sample }\end{array}$ & $\begin{array}{c}\text { Col 2: } \\
\text { Mean } \\
\text { Untreated }\end{array}$ & $\begin{array}{c}\text { Col 3: } \\
\text { Mean } \\
\text { Treated }\end{array}$ & $\begin{array}{c}\text { Col 4: } \\
\text { Diff } \\
(3)-(2)\end{array}$ & $\begin{array}{c}\text { Col 5: } \\
\operatorname{Pr}(|t|>c) \\
\end{array}$ \\
\hline \multicolumn{6}{|l|}{ Demographic } \\
\hline Age & 21.37 & 21.56 & 21.25 & 0.31 & 0.4647 \\
\hline \multicolumn{6}{|l|}{ Female (\%) } \\
\hline \multicolumn{6}{|l|}{ Race (\%) } \\
\hline Asian & $22.40 \%$ & $26.55 \%$ & $20.00 \%$ & 6.54 & 0.1852 \\
\hline Black & $35.71 \%$ & $23.01 \%$ & $43.08 \%$ & -20.07 & $0.0004^{* * *}$ \\
\hline Hispanic & $9.42 \%$ & $10.62 \%$ & $8.72 \%$ & $9.42 \%$ & 0.5833 \\
\hline White & $24.35 \%$ & $30.97 \%$ & $20.51 \%$ & 10.46 & $0.0394^{* *}$ \\
\hline Two or more races & $8.12 \%$ & $8.85 \%$ & $7.69 \%$ & 1.16 & 0.7211 \\
\hline \multicolumn{6}{|l|}{ Institutional } \\
\hline Entering GPA & 2.86 & 2.90 & 2.84 & 0.06 & 0.4416 \\
\hline Entering hours & 49.55 & 48.49 & 50.16 & -1.68 & 0.6488 \\
\hline \multicolumn{6}{|l|}{ Academic level (\%) } \\
\hline Freshman & $28.57 \%$ & $27.43 \%$ & $29.23 \%$ & -1.80 & 0.7375 \\
\hline Sophomore & $37.66 \%$ & $40.71 \%$ & $35.90 \%$ & 4.81 & 0.4027 \\
\hline Junior & $21.75 \%$ & $17.70 \%$ & $24.10 \%$ & -6.40 & 0.1904 \\
\hline Senior & $12.01 \%$ & $14.16 \%$ & $10.80 \%$ & 3.39 & 0.3794 \\
\hline \multicolumn{6}{|l|}{ Major (\%) } \\
\hline Pre-business & $53.90 \%$ & $48.67 \%$ & $56.92 \%$ & -8.25 & 0.1626 \\
\hline Business & $0.65 \%$ & $0.00 \%$ & $1.02 \%$ & $-1.03 \%$ & 0.2816 \\
\hline Economics & $2.92 \%$ & $4.42 \%$ & $2.05 \%$ & 2.37 & 0.2346 \\
\hline \multicolumn{6}{|l|}{ Math Experience (\%) } \\
\hline No math & $22.40 \%$ & $21.24 \%$ & $23.08 \%$ & -1.84 & 0.7103 \\
\hline Basic math & $0.65 \%$ & $0.00 \%$ & $1.03 \%$ & -1.03 & 0.2816 \\
\hline Pre-reqs & $47.08 \%$ & $48.67 \%$ & $46.15 \%$ & 2.52 & 0.6707 \\
\hline Trig or calc. & $13.31 \%$ & $12.39 \%$ & $13.85 \%$ & -1.45 & 0.7179 \\
\hline Advanced math & $16.56 \%$ & $17.70 \%$ & $15.90 \%$ & 1.80 & 0.6830 \\
\hline \multicolumn{6}{|l|}{ Performance } \\
\hline \# Pre-HW Completed & 8.31 & 8.76 & 8.05 & 0.71 & 0.0458 \\
\hline Pre-TUCE Score & 11.95 & 11.56 & 12.17 & -0.61 & 0.3104 \\
\hline Post-TUCE Score & 17.27 & 16.97 & 17.44 & -0.47 & 0.4324 \\
\hline Adjusted Progress & 0.27 & 0.28 & 0.27 & 0.01 & 0.8690 \\
\hline Online class $(\%)$ & $57.79 \%$ & $68.14 \%$ & $51.79 \%$ & 16.35 & $0.0050^{* * *}$ \\
\hline \multicolumn{6}{|l|}{ Class Grade (\%) } \\
\hline $\mathrm{A}$ & $39.61 \%$ & $38.94 \%$ & $40.00 \%$ & -1.06 & 0.8549 \\
\hline $\mathrm{B}$ & $30.84 \%$ & $29.20 \%$ & $31.79 \%$ & -2.59 & 0.6364 \\
\hline $\mathrm{C}$ & $15.91 \%$ & $17.70 \%$ & $14.87 \%$ & 2.83 & 0.5148 \\
\hline $\mathrm{D}, \mathrm{F}$, or $\mathrm{W}$ & $13.64 \%$ & $14.16 \%$ & $13.33 \%$ & 0.83 & 0.8393 \\
\hline \# Observations & 308 & & & & \\
\hline
\end{tabular}

Notes: $* \mathrm{p}<0.1, * * \mathrm{p}<0.05, * * * \mathrm{p}<0.01$ 
Table A3: Summary Statistics - Women Only

\begin{tabular}{|c|c|c|c|c|c|}
\hline & $\begin{array}{l}\text { Col 1: Mean } \\
\text { Full Sample }\end{array}$ & $\begin{array}{c}\text { Col 2: } \\
\text { Mean } \\
\text { Untreated }\end{array}$ & $\begin{array}{c}\text { Col 3: } \\
\text { Mean } \\
\text { Treated }\end{array}$ & $\begin{array}{c}\text { Col 4: } \\
\text { Diff } \\
(3)-(2)\end{array}$ & $\begin{array}{c}\text { Col 5: } \\
\operatorname{Pr}(|t|>c) \\
\end{array}$ \\
\hline \multicolumn{6}{|l|}{ Demographic } \\
\hline Age & 22.64 & 22.68 & 22.60 & 0.08 & 0.9110 \\
\hline \multicolumn{6}{|l|}{ Female $(\%)$} \\
\hline \multicolumn{6}{|l|}{ Race (\%) } \\
\hline Asian & $14.20 \%$ & $14.11 \%$ & $14.29 \%$ & -0.18 & 0.9633 \\
\hline Black & $47.34 \%$ & $50.92 \%$ & $44.00 \%$ & 6.92 & 0.2041 \\
\hline Hispanic & $9.47 \%$ & $7.98 \%$ & $10.86 \%$ & 2.88 & 0.3674 \\
\hline White & $21.30 \%$ & $20.25 \%$ & $22.29 \%$ & -2.04 & 0.6483 \\
\hline Two or more races & $7.69 \%$ & $6.75 \%$ & $8.57 \%$ & -1.82 & 0.5311 \\
\hline \multicolumn{6}{|l|}{ Institutional } \\
\hline Entering GPA & 2.91 & 2.93 & 2.90 & 3.27 & 0.6908 \\
\hline Entering hours & 59.39 & 63.98 & 55.11 & 8.87 & $0.0333^{* *}$ \\
\hline \multicolumn{6}{|l|}{ Academic level (\%) } \\
\hline Freshman & $21.89 \%$ & $18.40 \%$ & $25.14 \%$ & -6.74 & 0.1352 \\
\hline Sophomore & $35.50 \%$ & $33.74 \%$ & $37.14 \%$ & -3.40 & 0.5153 \\
\hline Junior & $24.56 \%$ & $26.38 \%$ & $22.86 \%$ & 3.52 & 0.4536 \\
\hline Senior & $18.05 \%$ & $21.47 \%$ & $14.86 \%$ & 6.62 & 0.1147 \\
\hline \multicolumn{6}{|l|}{ Major (\%) } \\
\hline Pre-business & $43.20 \%$ & $44.17 \%$ & $42.29 \%$ & 1.89 & 0.7274 \\
\hline Business & $0.89 \%$ & $0.61 \%$ & $1.14 \%$ & -0.53 & 0.6054 \\
\hline Economics & $2.96 \%$ & $3.68 \%$ & $2.29 \%$ & 1.40 & 0.4509 \\
\hline \multicolumn{6}{|l|}{ Math Experience (\%) } \\
\hline No math & $21.30 \%$ & $20.25 \%$ & $22.29 \%$ & -2.04 & 0.6483 \\
\hline Basic math & $0.30 \%$ & $0.61 \%$ & $0.00 \%$ & 0.61 & 0.3008 \\
\hline Pre-reqs & $57.40 \%$ & $57.69 \%$ & $57.14 \%$ & 0.53 & 0.9225 \\
\hline Trig or calc. & $9.17 \%$ & $10.43 \%$ & $8.00 \%$ & 2.43 & 0.4409 \\
\hline Advanced math & $11.83 \%$ & $11.04 \%$ & $12.57 \%$ & -1.53 & 0.6649 \\
\hline \multicolumn{6}{|l|}{ Performance } \\
\hline \# Pre-HW Completed & 9.02 & 9.23 & 8.83 & 0.39 & 0.1473 \\
\hline Pre-TUCE Score & 10.17 & 10.09 & 10.23 & -0.14 & 0.7576 \\
\hline Post-TUCE Score & 15.68 & 15.31 & 16.03 & -0.72 & 0.1853 \\
\hline Adjusted Progress & 0.26 & 0.23 & 0.29 & -0.05 & 0.1234 \\
\hline Online class $(\%)$ & $75.44 \%$ & $87.12 \%$ & $64.57 \%$ & 22.55 & $0.0000^{* * *}$ \\
\hline \multicolumn{6}{|l|}{ Class Grade (\%) } \\
\hline $\mathrm{A}$ & $36.39 \%$ & $33.13 \%$ & $39.43 \%$ & -6.30 & 0.2303 \\
\hline B & $25.44 \%$ & $25.77 \%$ & $25.14 \%$ & 0.62 & 0.8957 \\
\hline $\mathrm{C}$ & $20.12 \%$ & $21.47 \%$ & $18.86 \%$ & 2.62 & 0.5503 \\
\hline $\mathrm{D}, \mathrm{F}$, or W & $18.05 \%$ & $19.63 \%$ & $16.57 \%$ & 3.06 & 0.4662 \\
\hline \# Observations & 338 & & & & \\
\hline
\end{tabular}

Notes: $* \mathrm{p}<0.1, * * \mathrm{p}<0.05, * * * \mathrm{p}<0.01$ 
Table A4: Regression Results for All and High TUCE Students Excluding Pre-TUCE Scores

\begin{tabular}{|c|c|c|c|c|c|c|c|c|c|}
\hline & \multicolumn{3}{|c|}{ Adjusted Progress } & \multicolumn{3}{|c|}{ Total Points } & \multicolumn{3}{|c|}{ Pass/Fail } \\
\hline & $\begin{array}{l}\text { Col 1: } \\
\text { Full } \\
\text { Sample }\end{array}$ & $\begin{array}{l}\text { Col 2: } \\
\text { Male }\end{array}$ & $\begin{array}{l}\text { Col 3: } \\
\text { Female }\end{array}$ & $\begin{array}{c}\text { Col 4: } \\
\text { Full } \\
\text { Sample }\end{array}$ & $\begin{array}{l}\text { Col 5: } \\
\text { Male }\end{array}$ & $\begin{array}{l}\text { Col 6: } \\
\text { Female }\end{array}$ & $\begin{array}{l}\text { Col 7: } \\
\text { Full } \\
\text { Sample }\end{array}$ & $\begin{array}{l}\text { Col 8: } \\
\text { Male }\end{array}$ & $\begin{array}{l}\text { Col 9: } \\
\text { Female }\end{array}$ \\
\hline & \multicolumn{9}{|c|}{ Panel A: Main Specification } \\
\hline Adaptive Learning & $\begin{array}{c}0.0370 \\
(0.0204)\end{array}$ & $\begin{array}{c}0.00270 \\
(0.0577)\end{array}$ & $\begin{array}{l}0.0704^{* * *} \\
(0.0172)\end{array}$ & $\begin{array}{c}11.60 \\
(6.676)\end{array}$ & $\begin{array}{l}13.27^{*} \\
(6.763)\end{array}$ & $\begin{array}{c}11.21 \\
(12.14)\end{array}$ & $\begin{array}{l}0.0376^{* *} \\
(0.0133)\end{array}$ & $\begin{array}{c}0.0394 \\
(0.0311)\end{array}$ & $\begin{array}{c}0.0311 \\
(0.0344)\end{array}$ \\
\hline \# Pre-HW Completed & $\begin{array}{l}-0.00458 \\
(0.00642)\end{array}$ & $\begin{array}{l}-0.00594 \\
(0.00515)\end{array}$ & $\begin{array}{r}-0.00410 \\
(0.0105)\end{array}$ & $\begin{array}{l}18.44^{* * *} \\
(1.842)\end{array}$ & $\begin{array}{c}15.27^{* * * \# \#} \\
(2.503)\end{array}$ & $\begin{array}{c}23.28^{* * * \# \#} \\
(2.382)\end{array}$ & $\begin{array}{l}0.0448^{* * *} \\
(0.00599)\end{array}$ & $\begin{array}{c}0.0309^{* * * \# \#} \\
(0.00924)\end{array}$ & $\begin{array}{c}0.0644^{* * * \# \#} \\
(0.00842)\end{array}$ \\
\hline \multirow[t]{2}{*}{ \# Observations } & 646 & 308 & 338 & 645 & 308 & 337 & 646 & 308 & 338 \\
\hline & \multicolumn{9}{|c|}{ Panel B: Top $75^{\text {th }}$ Percentile Pre-TUCE } \\
\hline Adaptive Learning & $\begin{array}{c}-0.00137 \\
(0.0949)\end{array}$ & $\begin{array}{l}-0.0375 \\
(0.116)\end{array}$ & $\begin{array}{l}0.0701 \\
(0.140)\end{array}$ & $\begin{array}{c}15.89 \\
(11.35)\end{array}$ & $\begin{array}{c}13.01 \\
(14.73)\end{array}$ & $\begin{array}{l}7.576 \\
(13.24)\end{array}$ & $\begin{array}{c}0.0353 \\
(0.0240)\end{array}$ & $\begin{array}{c}0.0131 \\
(0.0166)\end{array}$ & $\begin{array}{c}0.0502 \\
(0.0349)\end{array}$ \\
\hline \# Pre-HW Completed & $\begin{array}{l}0.00625 \\
(0.0107)\end{array}$ & $\begin{array}{c}0.0135 \\
(0.0115)\end{array}$ & $\begin{array}{c}0.00303 \\
(0.0173)\end{array}$ & $\begin{array}{l}17.07^{* * *} \\
(1.914)\end{array}$ & $\begin{array}{c}14.49^{* * * \# \#} \\
(2.881)\end{array}$ & $\begin{array}{c}24.61^{* * * \# \#} \\
(4.285)\end{array}$ & $\begin{array}{c}0.0207^{*} \\
(0.0106)\end{array}$ & $\begin{array}{c}0.0120^{\#} \\
(0.00709)\end{array}$ & $\begin{array}{l}0.0459^{* \#} \\
(0.0231)\end{array}$ \\
\hline \# Observations & 178 & 113 & 65 & 178 & 113 & 65 & 178 & 113 & 65 \\
\hline & \multicolumn{9}{|c|}{ Panel C: Above Average Pre-TUCE } \\
\hline Adaptive Learning & $\begin{array}{c}0.0627 \\
(0.0462)\end{array}$ & $\begin{array}{c}-0.00288 \\
(0.0791)\end{array}$ & $\begin{array}{c}0.128^{* *} \\
(0.0430)\end{array}$ & $\begin{array}{l}28.01^{* * *} \\
(4.991)\end{array}$ & $\begin{array}{c}16.73^{* * *} \\
(4.395)\end{array}$ & $\begin{array}{c}40.21^{* * *} \\
(10.05)\end{array}$ & $\begin{array}{c}0.0818^{*} \\
(0.0386)\end{array}$ & $\begin{array}{c}0.0667 \\
(0.0398)\end{array}$ & $\begin{array}{c}0.0941^{*} \\
(0.0433)\end{array}$ \\
\hline \# Pre-HW Completed & $\begin{array}{c}0.00489 \\
(0.00711)\end{array}$ & $\begin{array}{c}0.00421 \\
(0.00505)\end{array}$ & $\begin{array}{l}0.00487 \\
(0.0123)\end{array}$ & $\begin{array}{l}18.36^{* * *} \\
(2.742)\end{array}$ & $\begin{array}{l}16.83^{* * *} \\
(3.353)\end{array}$ & $\begin{array}{c}20.53^{* * *} \\
(3.619)\end{array}$ & $\begin{array}{c}0.0286^{* *} \\
(0.00919)\end{array}$ & $\begin{array}{c}0.0273^{* *} \\
(0.00938)\end{array}$ & $\begin{array}{c}0.0276^{* *} \\
(0.00966)\end{array}$ \\
\hline \# Observations & 356 & 195 & 161 & 355 & 195 & 160 & 356 & 195 & 161 \\
\hline
\end{tabular}

Notes: All regressions control for age, gender, race, credit hours, GPA, major, math background, online status of the course, term completed, and number of prelecture homework assignments completed. Heteroskedastic robust standard errors clustered by section are in parentheses. Adjusted progress is defined as (PreTUCE - Post-TUCE)/(30 - Pre-TUCE). Coefficients for pass/fail are from a linear probability model. Statistically significant coefficients are indicated by * $p<$ $0.1,{ }^{* *} \mathrm{p}<0.05,{ }^{* *} \mathrm{p}<0.01$. Statistically significantly different coefficients for male vs. female are indicated by ${ }^{\#} \mathrm{p}<0.1,{ }^{\# \#} \mathrm{p}<0.05$, ${ }^{\# \#} \mathrm{p}<0.01$. 
Table A5: Regression Results for Low TUCE Students Excluding Pre-TUCE Scores

\begin{tabular}{|c|c|c|c|c|c|c|c|c|c|}
\hline & \multicolumn{3}{|c|}{ Adjusted Progress } & \multicolumn{3}{|c|}{ Total Points } & \multicolumn{3}{|c|}{ Pass/Fail } \\
\hline & $\begin{array}{l}\text { Col 1: } \\
\text { Full } \\
\text { Sample } \\
\end{array}$ & $\begin{array}{l}\text { Col 2: } \\
\text { Male }\end{array}$ & $\begin{array}{l}\text { Col 3: } \\
\text { Female }\end{array}$ & $\begin{array}{c}\text { Col 4: } \\
\text { Full } \\
\text { Sample } \\
\end{array}$ & $\begin{array}{l}\text { Col 5: } \\
\text { Male }\end{array}$ & $\begin{array}{c}\text { Col 6: } \\
\text { Female }\end{array}$ & $\begin{array}{c}\text { Col 7: } \\
\text { Full } \\
\text { Sample } \\
\end{array}$ & $\begin{array}{c}\text { Col 8: } \\
\text { Male }\end{array}$ & $\begin{array}{l}\text { Col 9: } \\
\text { Female }\end{array}$ \\
\hline & \multicolumn{9}{|c|}{ Panel A: Below Average Pre-TUCE } \\
\hline Adaptive Learning & $\begin{array}{c}0.0160 \\
(0.0260)\end{array}$ & $\begin{array}{c}0.0410 \\
(0.0442)\end{array}$ & $\begin{array}{c}0.0107 \\
(0.0387)\end{array}$ & $\begin{array}{c}2.898 \\
(20.21)\end{array}$ & $\begin{array}{c}8.910 \\
(15.91)\end{array}$ & $\begin{array}{c}0.146 \\
(24.97)\end{array}$ & $\begin{array}{c}0.0131 \\
(0.0379)\end{array}$ & $\begin{array}{c}0.0206 \\
(0.0654)\end{array}$ & $\begin{array}{c}0.0232 \\
(0.0296)\end{array}$ \\
\hline \# Pre-HW Completed & $\begin{array}{l}-0.00899^{*} \\
(0.00476)\end{array}$ & $\begin{array}{c}-0.00961 \\
(0.00727)\end{array}$ & $\begin{array}{c}-0.00659 \\
(0.00608)\end{array}$ & $\begin{array}{l}16.61^{* * *} \\
(3.261)\end{array}$ & $\begin{array}{l}12.22^{* * \#} \\
(5.263)\end{array}$ & $\begin{array}{c}21.45^{* * * \#} \\
(3.039)\end{array}$ & $\begin{array}{l}0.0594^{* * *} \\
(0.00784)\end{array}$ & $\begin{array}{c}0.0318^{* \# \#} \\
(0.0155)\end{array}$ & $\begin{array}{c}0.0843^{* * *} \\
(0.00617)\end{array}$ \\
\hline \multirow[t]{2}{*}{ \# Observations } & 290 & 113 & 177 & 290 & 113 & 177 & 290 & 113 & 177 \\
\hline & \multicolumn{9}{|c|}{ Panel B: Bottom 25 ${ }^{\text {th }}$ Percentile } \\
\hline Adaptive Learning & $\begin{array}{r}-0.00203 \\
(0.0378)\end{array}$ & $\begin{array}{l}-0.0321 \\
(0.0442)\end{array}$ & $\begin{array}{l}0.00798 \\
(0.0534)\end{array}$ & $\begin{array}{c}0.822 \\
(24.39)\end{array}$ & $\begin{array}{c}-10.42 \\
(18.28)\end{array}$ & $\begin{array}{c}2.949 \\
(24.20)\end{array}$ & $\begin{array}{c}0.0198 \\
(0.0583)\end{array}$ & $\begin{array}{c}-0.113 \\
(0.0792)\end{array}$ & $\begin{array}{c}0.0810^{*} \\
(0.0378)\end{array}$ \\
\hline \# Pre-HW Completed & $\begin{array}{l}-0.00598 \\
(0.00641)\end{array}$ & $\begin{array}{c}-0.0161 \\
(0.00990)\end{array}$ & $\begin{array}{l}0.00608 \\
(0.0124)\end{array}$ & $\begin{array}{l}20.01^{* * *} \\
(4.485)\end{array}$ & $\begin{array}{l}11.18^{\# \#} \\
(6.247)\end{array}$ & $\begin{array}{c}30.21^{* * * \# \#} \\
(4.169)\end{array}$ & $\begin{array}{c}0.0565^{* * *} \\
(0.0105)\end{array}$ & $\begin{array}{c}0.0210^{\# \# \#} \\
(0.0195)\end{array}$ & $\begin{array}{c}0.100^{* * * \# \# \#} \\
(0.0182)\end{array}$ \\
\hline \# Observations & 168 & 65 & 103 & 168 & 65 & 103 & 168 & 65 & 103 \\
\hline
\end{tabular}

Notes: All regressions control for age, gender, race, credit hours, GPA, major, math background, online status of the course, term completed, and number of prelecture homework assignments completed. Heteroskedastic robust standard errors clustered by section are in parentheses. Adjusted progress is defined as (PreTUCE - Post-TUCE)/(30 - Pre-TUCE). Coefficients for pass/fail are from a linear probability model. Statistically significant coefficients are indicated by * $p<$ $0.1,{ }^{* *} \mathrm{p}<0.05,{ }^{* * *} \mathrm{p}<0.01$. Statistically significantly different coefficients for male vs. female are indicated by ${ }^{\#} \mathrm{p}<0.1,{ }^{\#} \mathrm{p}<0.05$, ${ }^{\# \#} \mathrm{p}<0.01$. 
Table A6: Regression Results with (Adaptive Learning $\times$ Female) Interaction

\begin{tabular}{|c|c|c|c|}
\hline & $\begin{array}{c}\text { Col 1: } \\
\text { Adjusted Progress }\end{array}$ & $\begin{array}{c}\text { Col 2: } \\
\text { Total Points }\end{array}$ & $\begin{array}{c}\text { Col 3: } \\
\text { Pass/Fail }\end{array}$ \\
\hline & \multicolumn{3}{|c|}{ Panel A: Main Specification } \\
\hline \multirow[t]{2}{*}{ Adaptive Learning } & $0.0291^{\wedge}$ & 9.694 & $0.0319^{\wedge}$ \\
\hline & $(0.0465)$ & $(7.272)$ & $(0.0289)$ \\
\hline \multirow[t]{2}{*}{ Female } & -0.0787 & -13.22 & -0.0344 \\
\hline & $(0.0506)$ & $(13.17)$ & $(0.0370)$ \\
\hline \multirow[t]{2}{*}{ (Adaptive Learning $\times$ Female) } & $0.0275^{\wedge}$ & -1.016 & $0.000481^{\wedge}$ \\
\hline & $(0.0622)$ & (14.34) & $(0.0453)$ \\
\hline \multirow[t]{2}{*}{ \# Observations } & 646 & 645 & 646 \\
\hline & \multicolumn{3}{|c|}{ Panel B: Above Average Pre-TUCE } \\
\hline \multirow[t]{2}{*}{ Adaptive Learning } & $0.0534^{\wedge}$ & $15.69^{* \wedge \wedge}$ & 0.0730 \\
\hline & $(0.0605)$ & $(8.439)$ & $(0.0443)$ \\
\hline \multirow[t]{2}{*}{ Female } & -0.120 & $-17.10^{*}$ & 0.00297 \\
\hline & $(0.0669)$ & $(9.058)$ & $(0.0241)$ \\
\hline \multirow{2}{*}{ (Adaptive Learning $\times$ Female) } & $0.0567^{\wedge}$ & $15.14^{\wedge \wedge}$ & 0.00494 \\
\hline & $(0.0818)$ & $(13.12)$ & $(0.0410)$ \\
\hline \multirow[t]{2}{*}{ \# Observations } & 356 & 355 & 356 \\
\hline & \multicolumn{3}{|c|}{ Panel C: Below Average Pre-TUCE } \\
\hline \multirow[t]{2}{*}{ Adaptive Learning } & 0.0316 & 8.796 & 0.00829 \\
\hline & $(0.0227)$ & $(19.52)$ & $(0.0765)$ \\
\hline \multirow[t]{2}{*}{ Female } & -0.0240 & -2.678 & -0.0765 \\
\hline & $(0.0468)$ & $(21.09)$ & $(0.0644)$ \\
\hline \multirow[t]{2}{*}{ (Adaptive Learning $\times$ Female) } & -0.0114 & -10.66 & 0.00286 \\
\hline & $(0.0494)$ & $(25.80)$ & $(0.0873)$ \\
\hline \multirow[t]{2}{*}{ \# Observations } & 290 & 290 & 290 \\
\hline & \multicolumn{3}{|c|}{ Panel D: Top $75^{\text {th }}$ Percentile Pre-TUCE } \\
\hline \multirow[t]{2}{*}{ Adaptive Learning } & 0.0237 & $25.00^{*}$ & 0.0368 \\
\hline & $(0.0862)$ & $(13.26)$ & $(0.0266)$ \\
\hline \multirow[t]{2}{*}{ Female } & -0.147 & -12.68 & -0.0198 \\
\hline & $(0.138)$ & $(16.51)$ & $(0.0267)$ \\
\hline \multirow[t]{2}{*}{ (Adaptive Learning $\times$ Female) } & 0.0113 & -27.43 & -0.00573 \\
\hline & $(0.141)$ & $(26.71)$ & $(0.0333)$ \\
\hline \multirow[t]{2}{*}{ \# Observations } & 178 & 178 & 178 \\
\hline & \multicolumn{3}{|c|}{ Panel E: Bottom $25^{\text {th }}$ Percentile Pre-TUCE } \\
\hline \multirow{2}{*}{ Adaptive Learning } & 0.0349 & -3.813 & -0.0762 \\
\hline & $(0.0360)$ & $(29.27)$ & $(0.103)$ \\
\hline \multirow[t]{2}{*}{ Female } & -0.0205 & -5.902 & -0.144 \\
\hline & $(0.0590)$ & $(30.22)$ & $(0.0829)$ \\
\hline \multirow[t]{2}{*}{ (Adaptive Learning $\times$ Female) } & -0.00936 & 3.193 & 0.135 \\
\hline & $(0.0726)$ & $(35.69)$ & $(0.106)$ \\
\hline \# Observations & 168 & 168 & 168 \\
\hline
\end{tabular}

Notes: All regressions control for age, gender, race, credit hours, GPA, major, math background, online status of the course, term completed, number of pre-lecture homework assignments completed, and pre-TUCE score. Heteroskedastic robust standard errors clustered by section are in parentheses. Adjusted progress is defined as (PreTUCE - Post-TUCE)/(30 - Pre-TUCE). Coefficients for pass/fail are from a linear probability model. Statistically significant coefficients are indicated by $* p<0.1,{ }^{* *} \mathrm{p}<0.05,{ }^{* * *} \mathrm{p}<0.01$. Joint significance between the indicator variable for adaptive learning and the indicator variable for female is indicated by ${ }^{\wedge} p<0.1, \wedge \wedge p<0.05,{ }^{\wedge \wedge} p<$ 0.01 . 
Table A7: Full Regression Results

\begin{tabular}{|c|c|c|c|}
\hline & $\begin{array}{c}\text { Col 1: } \\
\text { Adjusted Progress }\end{array}$ & $\begin{array}{c}\text { Col 2: } \\
\text { Total Points }\end{array}$ & $\begin{array}{c}\text { Col 3: } \\
\text { Pass/Fail }\end{array}$ \\
\hline \multirow[t]{2}{*}{ Adaptive Learning } & $0.0442^{* *}$ & 9.140 & $0.0322^{* *}$ \\
\hline & $(0.0187)$ & $(6.711)$ & $(0.0123)$ \\
\hline \multirow[t]{2}{*}{ Age } & $0.00904^{* *}$ & $3.145^{* * *}$ & 0.00239 \\
\hline & $(0.00302)$ & $(0.711)$ & $(0.00156)$ \\
\hline \multirow[t]{2}{*}{ Female } & -0.0627 & -13.81 & -0.0341 \\
\hline & $(0.0405)$ & $(9.345)$ & $(0.0254)$ \\
\hline \multirow[t]{2}{*}{ Asian } & 0.00791 & 11.83 & 0.0528 \\
\hline & $(0.0613)$ & $(27.51)$ & $(0.0442)$ \\
\hline \multirow[t]{2}{*}{ Black } & -0.0385 & -19.97 & -0.0118 \\
\hline & $(0.0634)$ & $(22.80)$ & $(0.0460)$ \\
\hline \multirow[t]{2}{*}{ Hispanic } & -0.000493 & 3.687 & -0.00363 \\
\hline & $(0.0515)$ & (22.02) & $(0.0514)$ \\
\hline \multirow[t]{2}{*}{ Two or More Races } & 0.0169 & 12.58 & 0.0247 \\
\hline & $(0.0561)$ & $(16.91)$ & $(0.0567)$ \\
\hline \multirow[t]{2}{*}{ Entering GPA } & $0.0918^{* * *}$ & $47.89^{* * *}$ & $0.0996^{* * *}$ \\
\hline & $(0.0165)$ & $(6.693)$ & $(0.0140)$ \\
\hline \multirow[t]{2}{*}{ Entering Hours } & -0.000154 & 0.359 & $0.000995^{* *}$ \\
\hline & $(0.000734)$ & $(0.210)$ & $(0.000396)$ \\
\hline \multirow[t]{2}{*}{ Pre-business } & -0.0455 & $-12.74^{*}$ & $-0.0333^{*}$ \\
\hline & $(0.0378)$ & $(6.144)$ & $(0.0158)$ \\
\hline \multirow[t]{2}{*}{ Business } & 0.0343 & $40.34^{* * *}$ & 0.0136 \\
\hline & $(0.0918)$ & $(10.57)$ & $(0.0786)$ \\
\hline \multirow[t]{2}{*}{ Economics } & $0.0626^{*}$ & 12.96 & -0.0213 \\
\hline & $(0.0307)$ & (15.93) & $(0.0753)$ \\
\hline \multirow[t]{2}{*}{ Basic Math } & 0.0547 & -48.99 & 0.0289 \\
\hline & $(0.0589)$ & (32.48) & $(0.259)$ \\
\hline \multirow[t]{2}{*}{ Pre-reqs } & 0.0402 & -0.974 & 0.0163 \\
\hline & $(0.0447)$ & (7.799) & $(0.0288)$ \\
\hline \multirow[t]{2}{*}{ Trig or calc. } & $0.0795^{*}$ & $33.89^{* *}$ & $0.0955^{* *}$ \\
\hline & $(0.0426)$ & $(13.05)$ & $(0.0302)$ \\
\hline \multirow[t]{2}{*}{ Advanced math } & 0.0494 & 7.395 & -0.0139 \\
\hline & $(0.0495)$ & $(12.80)$ & $(0.0415)$ \\
\hline \multirow[t]{2}{*}{ \# Pre-HW Completed } & 0.000819 & $16.29^{* * *}$ & $0.0408^{* * *}$ \\
\hline & $(0.00424)$ & $(1.663)$ & $(0.00599)$ \\
\hline \multirow[t]{2}{*}{ Pre-TUCE Score } & $-0.0220^{* * *}$ & $8.100^{* * *}$ & $0.0164^{* * *}$ \\
\hline & $(0.00597)$ & $(1.544)$ & $(0.00391)$ \\
\hline \multirow[t]{2}{*}{ Online } & -0.00994 & $-42.52^{* * *}$ & $-0.0529^{* *}$ \\
\hline & $(0.0266)$ & $(8.115)$ & $(0.0179)$ \\
\hline \multirow[t]{2}{*}{ Spring Term } & 0.0216 & $-70.67^{* * *}$ & $0.0363^{* * *}$ \\
\hline & $(0.0228)$ & $(7.784)$ & $(0.0109)$ \\
\hline \multirow[t]{2}{*}{ Summer Term } & $0.0622^{* *}$ & $-27.82^{* * *}$ & $-0.0535^{* * *}$ \\
\hline & $(0.0236)$ & $(4.589)$ & $(0.0153)$ \\
\hline \# Observations & 646 & 645 & 646 \\
\hline
\end{tabular}

Notes: All regressions control for age, gender, race, credit hours, GPA, major, math background, online status of the course, term completed, number of pre-lecture homework assignments completed, and pre-TUCE score. Heteroskedastic robust standard errors clustered by section are in parentheses. Adjusted progress is defined as (Pre-TUCE - Post-TUCE)/(30 - Pre-TUCE). Coefficients for pass/fail are from a linear probability model. Base categories of white, no math background, and Fall term are excluded from the estimation. Statistically significant coefficients are indicated by $* \mathrm{p}<0.1, * * \mathrm{p}<0.05, * * * \mathrm{p}<0.00$ 
Figure A1: Introduction: Adaptive Learning Courseware, McGraw Hill Connect
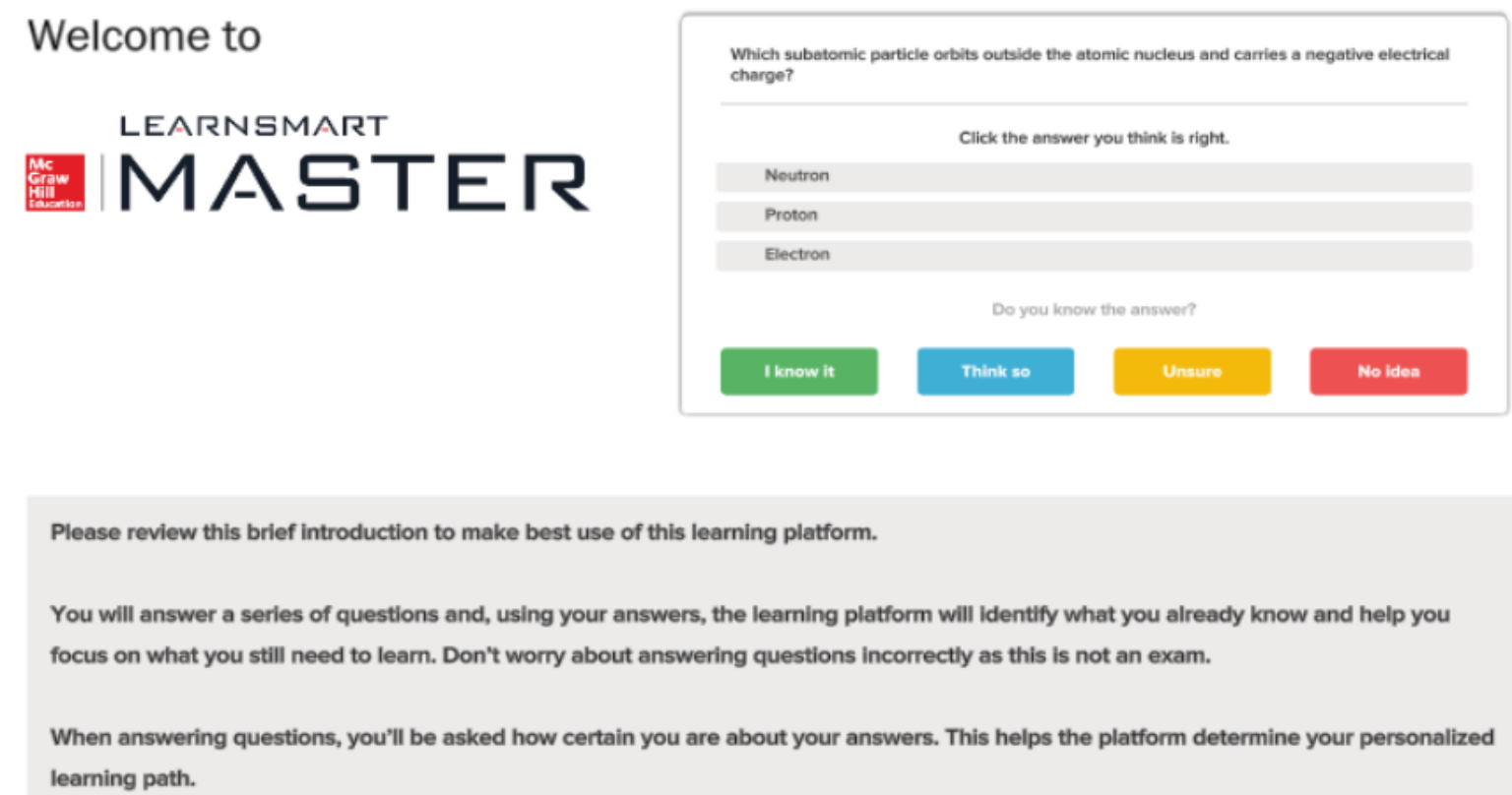

\section{Show Mel}

Figure A2: Progress Report: Adaptive Learning Courseware, McGraw Hill Connect

\begin{tabular}{|l|l|l|l|l|l|}
\hline 1 & Prep Majors Biology & Due: 19 Jun 2017 & $100 \%$ & Done & $\mathbf{Q}$ \\
\hline 2 & Prep Majors Blology & Due: 31 Jul 2017 & $100 \%$ & Done & $\mathbf{Q}$ \\
\hline 3 & Prep Majors Biology & Due: 31 Aug 2018 & $26 \%$ & On Track & > \\
\hline 4 & Prep Majors Blology & Start 15 Sep 2017 & Not Started Yet & $\mathbf{Q}$ \\
\hline
\end{tabular}

You will make progress as you answer questions correctly and your progress will be saved automatically as you work. Take breaks as needed: you can come back at a later time to complete your learning.

You can review more detailed information about your progress and performance in Reports, listed in the menu on the left.

You can also refresh your memory using Recharge, which will guide you through a review of material you have already mastered. Recharge is also listed in the menu on the left. 
Figure A3: Remediation: Adaptive Learning Courseware, McGraw Hill Connect

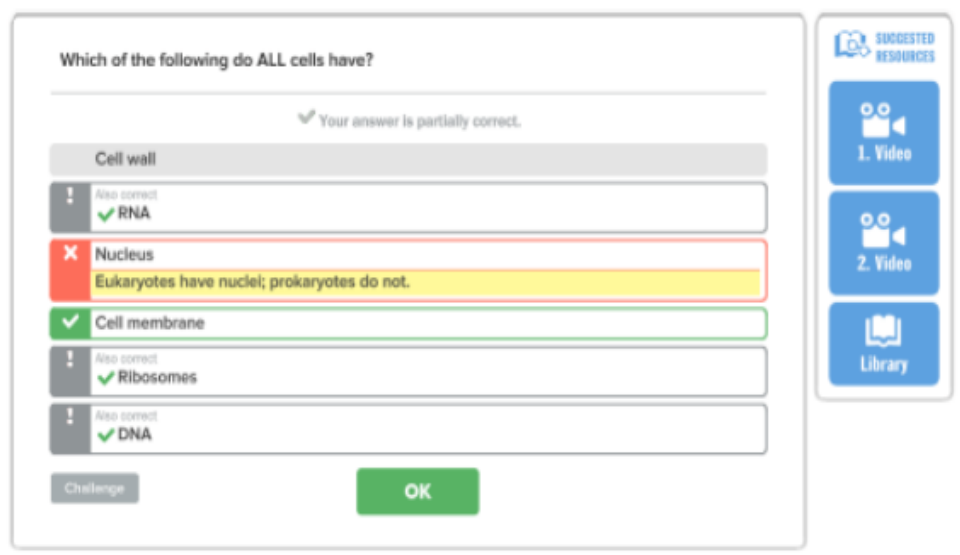

If you are struggling with a topic, the learning platform will provide a learning resource to cover the concept in detail. Spend time reviewing this resource and apply your knowledge to future questions.

You can also access additional course learning resources at any time in the Library, listed in the menu on the left. 
Figure A4: Individualized Learning Path Sequence, McGraw Hill Connect

\section{Figure A4.A: First question on monetary policy}

he money market in the United States and the investment urve are as shown in the two graphs below.

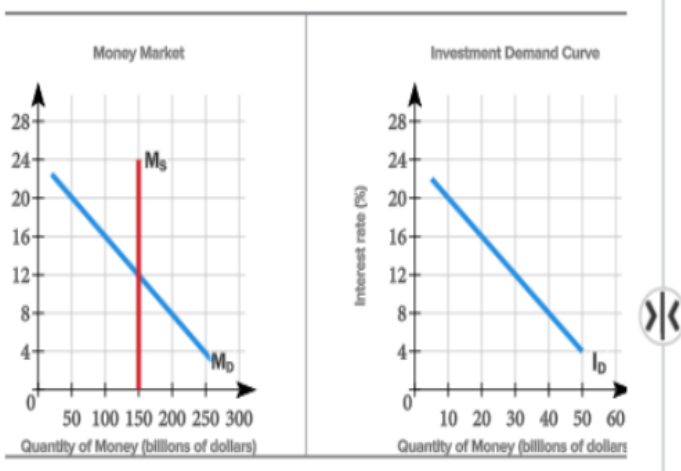

The current equilibrium interest rate in the money market is $\%$. (Do NOT press Enter after typing the answer in each cell. Use Tab or take the cursor to the next cell.) (Do not enter the percentage sign in the answer cell.) At this interest rate, there will be $\$ \square$ billion of investment spending in the economy.

\section{Submit}

Do you know the answer?

\section{I know it

ASSIGNMENT PROGRESS: Monetary Policy - Learning Activity 5\% 
Figure A4.B: Feedback on monetary policy

The current equilibrium interest rate in the money market is $\odot 12$ $\%$.

\section{내 애}

(Do NOT press Enter after typing the answer in each cell. Use Tab or take the cursor to the next cell.) (Do not enter the percentage sign in the answer cell.) At this interest rate, there will be $\$ \otimes{ }_{150}$ billion of investment spending in the economy.

You've missed this topic at least twice.

Before we continue, you need to review.

Click $0 \mathrm{~K}$ and we'll help you.

Your answer is partially correct.

\section{Challenge}

\section{OK}

ASSIGNMENT PROGRESS: Monetary Policy - Learning Aetivity 5\%

Figure A4.C: First remediation on monetary policy

Interest Rates and Investment: Worked Example

\section{Problem Statement}

Suppose the money market in the United States and the investment demand curve are as shown in the two graphs.

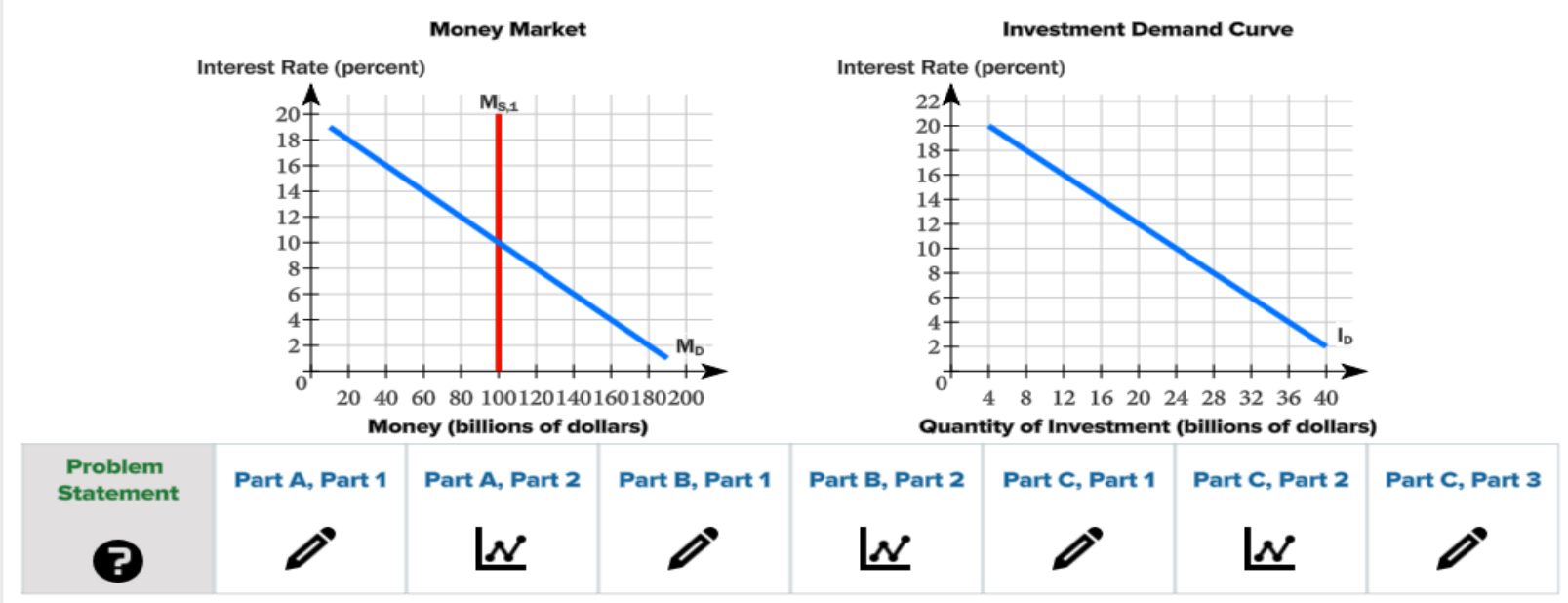

ASSIGNMENT PROGRESS: Monetary Policy - Learning Activity 5\% 
Figure A4.D: Second exposure to monetary policy

se the money market in the United States and the investment id curve are as shown in the two graphs below.

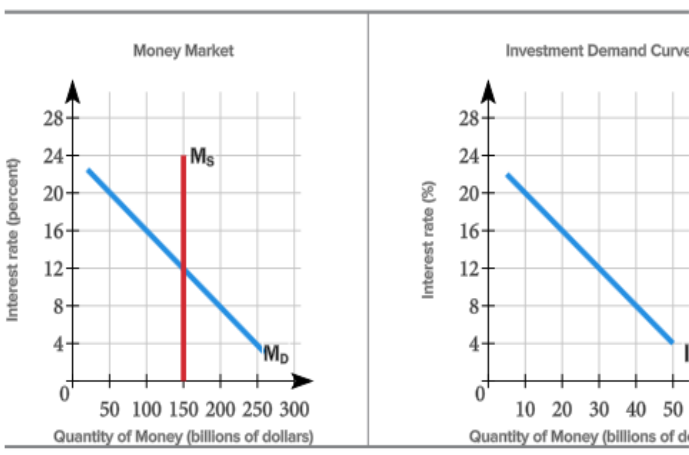

Suppose the Federal Reserve were to increase the money supply by $\$ 50$ billion.

This will result in a Select... $\quad \nabla$ of money because the demand for money

Select... $\quad \nabla$ the supply of money.

The new equilibrium interest rate in the money market is $\%$.

At this interest rate, there will be $\$ \square$ billion of investment spending in the economy.

(Do NOT press Enter after typing the answer in each cell. Use Tab or take the cursor to the next cell.)

水

Submit

Do you know the answer?

I know it

ASSIGNMENT PROGRESS: Monetary Policy - Learning Activity 5\%

Figure A4.E. A follow-up remediation on Monetary Policy

Video for Interest Rates and Investment

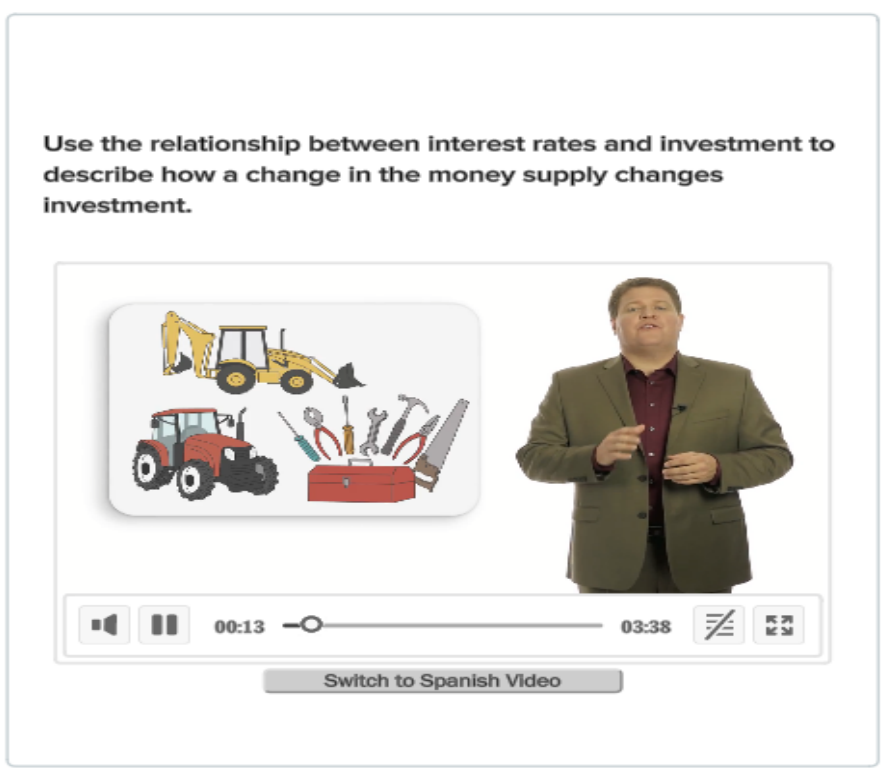

GIVE FEEDBACK

\section{Key Terms}

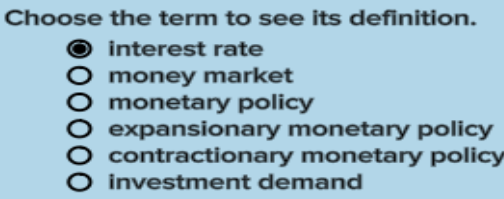

\section{Definitions}

The payment made to agents that lend or save money, expressed as an annualized percentage of the monetary amount lent or saved. Sometimes called nominal interest rate or price of money.

ASSIGNMENT PROGRESS: Monetary Policy - Learning Activity 5\% 


\section{Appendix B}

The APLU provided the following guidelines for choosing an adaptive learning platform.

1. Includes algorithms that adapt the goals or standards for learner completion based on more inputs than a single correct response to the previous item or activity.

2. Includes algorithms that adapt the scope of instruction based on more inputs than a single correct response to the previous item or activity.

3. Includes algorithms that adapt the sequence of instruction based on more inputs than a single correct response to the previous item or activity.

4. Includes algorithms that adapt the presentation of content based on relevance to career alignment or learner-declared goals.

5. Includes algorithms that adapt the complexity of presentation of content based on a learner pre-test.

6. Includes algorithms that adapt the complexity or presentation of content based on a learner's affective states.

The courseware suppliers and products that met these criteria at the time of the study include the following:

1. Acrobatiq

2. Cerego

3. CogBooks

4. Fishtree

5. Fulcrum Labs

6. Junction Education

7. Knewton

8. LeAP by D2L

9. Difference Engine by Learning Objects (Cengage)

10. LoudCloud
11. Lumen Waymaker

12. McGraw Hill Education ALEKS

13. McGraw Hill Education LearnSmart

14. Macmillan Learning Curves

15. Open Learning Initiative at Carnegie Mellon University
16. Open Learning Initiative at Standford University

17. OpenStax Tutor

18. Pearson MyLab \& Mastering (with Knewton)

19. Realizeit

20. Smart Sparrow

21. WileyPlus with ORION (Snapwiz) 